\author{
Daivis Petraitis* \\ The General Jonas Žemaitis Military Academy of Lithuania**
}

\title{
The Anatomy of Zapad-2017: Certain Features of Russian Military Planning
}

All Zapad exercises which took place after the collapse of the former Soviet Union (in 1999, 2009, 2013 and 2017) attracted the attention of neighboring countries and led to different estimates and conclusions. Every exercise had something particular happening which could not be explained or understood in the West. Step by step, while analyzing Zapad exercises and changes in Russia and its armed forces, sufficient information was gathered allowing for the partial explanation of the behavior of Russian forces during different exercises, and the reasons why they acted in such a manner.

Contrary to NATO and a majority of Western countries, the Russian military plans and executes military activities differently. This could be explained by the czarist and Soviet military giving preference to Prussian General Staff (GS) traditions and philosophy. The General Staff, which advocated its own methods, allowed the national leadership to manage and use military instruments more effectively. The recent Russian military tends to keep those traditions alive, while believing that modern technological progress could reduce (if not eliminate) the weaknesses of the Prussian GS philosophy and increase its stronger aspects. The Russian military believes that detailed operation planning in advance, with synchronization of actions in its core and the ability of forces to implement plans and the leadership to control and command an entire operation can turn the military into an effective fighting and foreign policy tool.

Zapad exercises have shown that they are used to test the concept and planning of a potential Russian war with a strong opponent in the West (Zapad operation). The concept and plan are both backed up with adequate assumptions. An entire operation (war) is planned to be waged in three stages. The essence of the war (and plan) is a synchronization of military actions in time and space. Since 1999, all of this has been tested, in the earlier years in separate stages, and during Zapad 2017 tests were carried out in a more complex way and covered all three stages.

It is worth to note that at least two times (in 2009 and 2017), Russia used Zapad exercises not only to test its plans and troops, but as a deception and strategic communication message as well. It appears that in both cases, some success was achieved.

\footnotetext{
* Major (ret.) Daivis Petraitis is a Deputy Director of the Department of International Relations and Operations of the Ministry of National Defence of the Republic of Lithuania. Address for correspondence: Totorių g. 25/3, LT-01121 Vilnius, tel.+370 5 2785237, e-mail: petraitisd@yahoo.com .

** This study was commissioned by the General Jonas Žemaitis Military Academy of Lithuania. Contract no. 8P-7, 13 November 2017.

${ }^{* * *}$ The assessment and ideas presented in this study are exclusively those of the author and can never be considered an official position of the Ministry of National Defence of the Republic of Lithuania or its departments.
} 


\section{Introduction}

The Russian military tends to believe that the success of any military operation depends not only on the preparation of soldiers and units, but on how well an operation is prepared and planned as well. This is best illustrated by a historical case, where before launching an assault on the Izmail fortress, the famous Russian general A. Suvorov, so as to support his belief that "difficult training makes for an easy battle", gave orders to build a mock fortress and to train as close to reality as possible.

Since then, the Russian military adopted numerous Prussian military traditions. The Russian czarist, Soviet and recent Russian Federation General Staff continues to devote great attention to implementing the principles of the Prussian General Staff, which emphasized military operations planning as essential. Whilst undergoing training in czarist, Soviet or more recently, the Russian General Staff Academy, Russian officers were taught that the success of any operation depends on how well all its steps are planned and synchronized in time and space, and how well troops are trained to perform all the actions foreseen for them in the plans. If we are to believe the recently-published memoirs of former Soviet generals, the Soviet Union's plans to fight NATO were quite detailed and synchronized in time and space. The forces were only expected to implement those plans. General Staff officers were considered the elites of the command and control system with the right to not only advice commanders but also, if necessary, to guarantee the success of plans, to issue orders on behalf of commanders ${ }^{1}$.

Traditions and experience remained important. This meant that the first Russian Federation defense plan of 2013-2015 signed by Russian President Putin in January $2013^{2}$, and its update (2016-2020), signed in November 2015, were quite detailed, describing all the specific actions (not only military related) to be carried out by all the state agencies. In essence, they are more similar to what is known in NATO as a standing Defense Plan (SDP), only broader in their scope. According to different sources, the Plan for 2016-2020 contains a number of situational annexes and foresees involvement of more than fifty different institutions, ministries and companies. And one of those likely annexes is the one devoted to a war against a technologically-advanced opponent in the West.

\footnotetext{
${ }^{1}$ The Soviet General Staff: A command structure for military planning and operations, CIA, May, 1982, unclassified on May 4, 2010 (CIA-RDP83T00233R000100170002-4)

${ }^{2}$ TV news "Vesti", 20130129
} 
Results arriving from an analysis of Zapad exercises from 1999 (especially (Zapad-09 and Zapad-13) allows one to assume that these exercises were used to test Russia's ability to fight in a war with a similar or stronger opponent. In the study, the scenario for a potential war with the West is called a "Zapad operation". A majority of Cold War waging principles remained, but modifications had been made by taking into account the new realities. First - Russia no longer possesses the Soviet Union's military power. Second, the geopolitical situation is different - the West would not be fighting communists in an ideological confrontation, but a capitalistic national state in an ordinary war.

The General Staff Main Operational Directorate (Главное оперативное управление ГШ ВС РФ) was the main body compiling the "Zapad operation" concept and plan. The other directorates of the General Staff were involved in the creation of capabilities necessary to implement it ${ }^{3}$. The creation of "Zapad operation" concept and plan is related to Army General J. Balujevskij name as well. While heading the Main Operational Directorate, he supervised the development of a theoretical plan for the "Zapad operation". Later, when he became the first deputy of the Chief of General Staff (2001-2004), and the chief of General Staff (2004-2008), the plan already existed, but the capabilities to implement it were not yet present. The General Staff under his leadership became responsible for the creation of those capabilities/forces. Plans were made to introduce these reforms for the creation of such forces, with over a decade given as the time period for their implementation ${ }^{4}$. The first stage of the reforms that finished in 2015 created the bulk of the forces ${ }^{5}$ and this allowed the first Russian state defense plan to be signed.

While working on the study, it was mainly official Russian MOD and other agencies' information messages, unclassified Russian normative documents, teaching material and other analytical material such as conferences, interviews, briefings or video (mostly Russian) that were used. Some open and declassified Western analytical documents were also reviewed. All this allowed creating a "Zapad operation" description, and to later follow how it was tested during different Zapad exercises.

There is almost no doubt that in the event of a military conflict with the West, Russian allies would be involved, but only Russian actions were analyzed in the study. This was done deliberately. The Russian "Zapad operation" is a

\footnotetext{
${ }^{3}$ The Soviet General Staff: A command structure for military planning and operations, CIA, May, 1982, unclassified on May 4, 2010 (CIA-RDP83T00233R000100170002-4).

${ }^{4}$ D. Petraitis, “The Russian Military Reform 2005-2015”, Lithuanian Annual Strategic Review, 2010-2011, vol. 9.

${ }^{5}$ D. Petraitis, “The New Face of Russiass Military”, Lithuanian Annual Strategic Review, 2014-2015, vol. 13.
} 
war where the worst-case scenario, the massive nuclear war, is foreseen, but Russia does not plan/seek to escalate the confrontation to this level. So even though a Russian-Belorussian military group participates in Zapad exercises with specific tasks assigned to it, the main expectations are placed on purely Russian capabilities, or more precisely, just some of them. Even though active military action during Zapads took place in other Russian JSCs as well, I lacked sufficient evidences to prove that those forces were part of a "Zapad operation". Forces from other JSCs should be taken only as a second echelon (supporting or reserve force), because, as it has been mentioned, widening of the conflict would endanger achieving success.

\section{A Zapad Operation. Planning and Execution}

Based on the available information, scenario analyses and actions performed during different Zapad exercises, one could state that a "Zapad operation" consists of three stages. The first stage is a sudden attack and a capture of bridgeheads, later entrenching and defending them. This might last from one to a few weeks. The second stage is safeguarding and extending achievements and trying to stabilize/terminate the conflict. This stage could last from one to three months. And the third stage is a massive (total) state defense all state assets involved and even moving onto a nuclear war if the defense fails. The entire length of a Zapad operation might be up to a year, the first two stages lasting from four to six months

After the first and second stages, time breaks are planned. During those periods, the intensity of actions is to be reduced. Those time breaks are aimed to achieve two tasks. At first, they are used to collect/reinforce forces to run a following stage. At second, they are used to persuade the opponent to move to a conflict solution by non-military means. The Russian military made the assumption that Western national political elites would consider the conflict as different compared to the Cold War times when the USSR was planning to destroy the entire Western social system. This conflict would be taken as a conflict with another capitalistic state fighting for its national interests. Given such a situation, it would be in the West's interest not to escalate the situation to mass destruction and to negotiate. Western behavior after the Georgian war and Crimea partially convinced Russians that they are right in this assumption. It is also very important to end each stage in an increasing trend. This might become a form of psychological pressure demonstrating to the opponent that neglecting the opportunity to negotiate would lead to outcomes that would be in Russia's favor. 
After an analysis of different Zapad scenarios and activities performed by troops, I can state that the principles of detailed planning are kept and the exercises are designed to test the leadership's (HQs) ability to command and control the situation according to the plan and the abilities of troops/units to act accordingly or to react to and receive commands/inputs.

The checking of any detailed plan has its certain features. The most important thing is to check the synchronization of actions which depend on time and space parameters. The plan can be checked efficiently only when those parameters are minimally distorted, or put simply, are close to real time (period) and real space (distances). If they are compressed (distorted) into a short time and space exercise framework, it would not be possible to test synchronization. Only the ability of participants to perform the prescribed activities would be tested in this case.

So, testing a detailed plan during short time exercises is difficult (if at all possible). Also, this implies a huge number of participants, because all the troops involved/planned for all stages have to participate. Without any doubt, this would arouse the suspicion of neighboring countries. And again, only the ability of troops to perform a certain action would be tested. Short time exercises do not allow testing a more important thing - the ability of different units and HQs to act in a synchronized manner and present a timely reaction to the inputs received, and the political-military leadership to control and command the entire operation. This is possible only having the exercise run for almost as long as the operation itself.

Not a single Western country can allow itself such a "pleasure". At first, after the Cold War, NATO and a majority of countries gave up updating their SDPs and relied more on so-called Contingency Operation Plans (COP). These are quite abstract and general. In case of danger, a COP is updated and transformed into a SDP. So, in the West, in order to have long-term exercises, an HQ must be established/appointed which can transform a COP into a SDP, then establish an adequate $\mathrm{C} 2$ and finally, summon the required troops to exercises. A majority of these elements are absent in peace time and have to be augmented, mobilized or established.

The situation is different in Russia. In 2014, the National Defense Management Center (NDMC) was established as a structural part of the General Staff. The General Staff/NDMC is responsible for implementation of the State Defense Plan. The NDMC, as a standing part of the GS, is able to perform as a training HQ and to test "Zapad operation". C2 and its extension to C3 is being created right now under the recent military reforms. To conclude, 
the structure and C3 framework already exist and there is no need to have anything additional created or mobilized to run a long-term exercise. There is another problem - the official announcement of a long-term exercise could reveal a real plan and draw attention. To avoid that long-term effect, the Russians apply their experience in secrecy and deception.

In order to run this kind of exercise and at the same time avoid drawing attention and reveal the plan, deception and secrecy (the famous maskirovka) are used. The clue here is to hide a long-term exercise within other military activities. In the case of Zapad, under the cover of officially-announced preparation for Zapad exercise (usually four to six months before the official dates), different "Zapad operation" stages/elements are tested. Because of other military activities conducted simultaneously, the exercise is masked as planned training or hidden among the other military activities being performed. This approach allows for "undercover" testing of "Zapad operation" activities lasting almost as long as planned or being initiated at a pre-planned time. It allows testing the most important thing - the ability of units to act in a synchronized manner (in time and space) and HQs to control this synchronization.

As mentioned, one of the most important preconditions allowing this to happen is an availability of overall $\mathrm{C} 3$ covering all command levels and territories. In Russia, the C3 is based on stationary (стационарные пункты управления) and mobile/field (полевые пункты управления) communication posts and facilitates the exchange of information and to send/receive commands/inputs from a tactical to a strategic level over distances of thousands of kilometers. Again, the General Staff (Main Communication Directorate) is responsible for the establishment of such $\mathrm{C}^{6}$, and military signal and command units are responsible for running this network ${ }^{7}$.

Moreover, the method of spreading exercises over time allows using official exercises for demonstrative-propagandist purposes directed at internal and foreign audiences as well. Based on the highlights shown during different official Zapads, one could draw the conclusion that during the officially announced Zapad (usually lasting up to a week), only a certain stage or element of a "Zapad operation" is shown. Russia could choose the stage which favors Russian interests, considering the particular security situation at the time. This is how an official exercise is transformed into something similar to a Western Distinguished Visitors Day (DVD) event.

Also, as a result of the military reform, Russia switched from territorial to extra-territorial usage of troops. Today, all Russian forces must be able to

\footnotetext{
${ }^{6}$ See Russian MOD homepage, General Staff section, http://eng.mil.ru/en/structure.

${ }^{7}$ In the JSC level those are represented by Signal (territorial) brigades or other signal units.
} 
fight in unknown locations when they are needed. This means different " $\mathrm{Za}$ pad operation" elements can be tested in locations outside the western parts of Russia, therefore some Zapad training could be done (and is done) in other Russian regions (central, eastern, etc.) as well ${ }^{8}$.

\section{Analysis of Zapad Exercises}

Let's return to the previous Zapad exercises. After the Zapad-81 exercise and break-up of the Soviet Union, Zapad exercises were no longer conducted. It appeared to everybody at that time that Russia was willing to cooperate rather than to confront NATO. The first indications of a change appeared in 1999 when Russia began to behave strangely while initiating activities leading to a confrontation. The checking of a potential NATO response to those activities was performed as well. The $11^{\text {th }}$ of June 1999 was the official end of the Kosovo war. Russia, with NATO, had to start a joint peace-keeping operation the next day (12 $2^{\text {th }}$ of June). Instead of this, a famous Russian paratrooper's jump into the Pristina airport happened. A battalion of paratroopers suddenly commenced a march of a few hundred kilometers, entered the airport and started preparing for defense and receiving reinforcements. Then NATO troops arrived, they were not allowed to enter the airfield and, based on videos from that time, nobody even tried to explain to them what was happening. The same video showed ordinary Russian paratroopers having no idea of what was happening. They simply kept carrying out orders. So, what was happening? After many years, the commanding officer of those paratroopers, Russian "SPECNAZ" major, Yunus-bek Bamatgireyevich Yevkurov confessed that after the arrival, paratroopers found the airport already being controlled by Russian "SPECNAZ" soldiers. According to their claims, "SPECNAZ" had been sitting clandestinely in the airport already since May. Yevkurov had an order to defend the airport without any idea why and for how long. ${ }^{9}$. Paratroopers were only performing orders and implementing the plan. Seemingly, this was one of the first attempts of the Russian General Staff to check NATO's reaction to provocative Russian actions. NATO gave up, started a dialog and Russian soldiers remained in Pristina. Then the General Staff carried out their next check - Zapad- $99^{10}$.

\footnotetext{
${ }^{8}$ D. Petraitis, „The Russian Military Reform 2005-2015“, Lithuanian Annual Strategic Review, 2010-2011, vol. 9. ${ }_{9}^{9}$ Documentary movie Генерал без биографии. Петр Ивашутин „ Russia.tv, https://russia.tv/video/ show/brand_id/61426/...id/.../1569986/.

10 “Россия планирует брать Запад на испуг”, Kommersant, 10-07-99.
} 


\subsection{Zapad-99}

Zapad-99 took place when Russian armed forces were in very poor shape and had almost no full flesh units in the fields. All three stages of a " $\mathrm{Za}$ pad operation" (including the nuclear one) were planned by General Staff ${ }^{11}$ and were played out mostly theoretically in HQs. The exercise (plan) included new military structures (Joint Strategic Commands) ${ }^{12}$ which did not exist at that time and were created only during the reform of 2008. Only a small amount of indicating troops (up to a company) representing military districts and fleets were in the field, but the total number of participants reached fifty thousand ${ }^{13}$. If we compare Zapad-99 with today's situation, there was one essential difference at that time. The potential attack targets, the Baltic States, were not NATO members. Back then, the Russian military had the idea to check (and to scare) NATO with a potential occupation of the Baltic States. An assumption was made that NATO would not risk starting a war (including nuclear) and wide-scale massive defense would not be needed. It would be enough only to capture the Baltics suddenly and threaten NATO with one or two nuclear strikes to force it to go the negotiation table.

After Zapad-99, strategic exercises were postponed for quite a long time. Right after Zapad-99 it was announced that the next exercise would be in two years. According to Russian General Staff statements today, strategic level exercises are to be held in every military district every fourth year, so the next Zapad had to be held in 2001 or 2003. Neither one happened. And in 2007, it was the same. There was a simple explanation for such a pause, Russia had a plan which was checked, but forces were absent. The country was preparing for a wide-scale military reform to create such forces, so all the time and effort until the official declaration of the reform (October $15^{\text {th }} 2008$ ) was devoted for preparation and experimentation ${ }^{14}$. Besides, in 2003 it was almost certain that the Baltic States would be invited to join NATO but Russia still had no forces to run a Zapad type of operation. Those forces did not exist in 2007 either and even more at the end of 2008, as soon as the reform started, the situation became critical. According to military estimates, Russia faced a situation where it had almost no forces for state defense. Time was needed for their creation. To solve that problem, the Zapad 2009 exercise was used as well.

\footnotetext{
11 “Утечка из военной разведки", Завтра, 6-07-99, http://zavtra.ru/blogs/1999-07-0614.

12 “Запад-99”, Правда, 2406 1999, https://www.pravda.ru/news/world/24-06-1999/903671-0/.

13 “Запад-99”, Правда, 2406 1999, https://www.pravda.ru/news/world/24-06-1999/903671-0/.

${ }^{14}$ D. Petraitis, "Reorganization of the Russian Armed Forces”, FNDU, Helsinki, 2012.
} 


\subsection{Zapad-09}

Zapad-09 was the first exercise conducted after Russia started its military reform. As it was mentioned, old units were disbanded or reformed, soldiers were retired and the creation of new units commenced. At one point in the spring of 2009, Russia had only five new-type brigades available ${ }^{15}$, and the rest were under reformation or creation. Forces were so limited and weak that they would not have been able to withstand even the weakest offense on Russia. An approved State Defense Plan was absent also. The Russian political military leadership thought this weakness of their conventional forces could become a "window of opportunity" for the West (NATO) to attack Russia. Given this, alongside testing their new forces, it was also very important to gain time. Deterring the West from any temptation to consider military actions against a weak Russia was a way of winning some time. Even though the newly-formed forces were already sufficient for assembling the numbers announced for Zapad-09 ${ }^{16}$, the main accent in the official Zapad-09 exercise was simulation of a tactical nuclear weapons application. Officially, Zapad-09 emphasized the second stage of a "Zapad operation" - termination of a conflict with nuclear assets. I failed to find anything credible in open Russian sources stating Warsaw being a nuclear strike target. Only strategic communication specialists could explain how a simple simulation of a tactical nuclear strike in general became a famous nuclear attack on Warsaw in particular, but the strategic communication effect was achieved. The West concentrated on this message, debates and consultations started and Russia won the time it needed to strengthen its conventional forces.

Nevertheless, the "Zapad operation" in 2009 was tested according to all the above-mentioned principles: extension in time and geography. The test started much earlier, in July, then an exercise under the code name " $A u$ tumn-09" (“Осень-2009”) began. Besides the official Zapad-09 exercise, it included exercises like "Ladoga-09" and "Caucasus-09" as well. At that time the Russian political-military leadership was not afraid to speak openly. The commander of Russian land forces General-Lieutenant S. Skokov even gave an extensive interview about "AUTUMN-09"17. It is worth pointing out that later,

\footnotetext{
${ }^{15}$ Г. Миранович, А. Худолееи, А. Земляниченко, “Бригады набирают силу”, Красная Звезда, 17022010.

${ }^{16}$ Officially, around 12,500 troops, 700 tanks, IFVs, APCs and 250 artillery systems, 100 airframes. In the field, about the same...

17 “Активная фаза учений «Запад-2009» пройдет на полигоне в Беларуси”, Москва, РИА Новости, 2909 2009, https://ria.ru/defense_safety/20090929/186789728.html.
} 
in 2013 and 2017, nobody even mentioned anything similar to the AUTUMN exercises.

The first stage of the "Zapad operation", a sudden assault and capture of territories, was tested episodically, in an open and hidden manner, mostly on the training grounds of Zapad-09. The imitation forces were represented by units up to a battalion in size. The third stage of the Zapad operation - massive defense - was not tested due to the absence of a new massive defense concept and its elements (a new mobilization system, for example). Among other problems not allowing expansion of the exercise was the absence of an actually working C3. The situation with C2 and C3 in the reformed armed forces was very bad. The president of Russia at that time, D. Medvedev, while talking to journalists confessed that up to 85 percent of the equipment in units was obsolete and not usable ${ }^{18}$.

\subsection{Zapad-13}

The official Zapad-13 took place when the Russian armed forces were almost reformed, with a bulk of the new units already formed and army general S. Shoigu, famous for his organizational skills, appointed as defense minister. The appearance of the reformed forces allowed Russia to have its first State Defense Plan for 2013-2015 signed in the history of the "New Russia"19. The plan assigned conventional forces their own tasks and places. Tested in October 2012, the Russian nuclear triad ${ }^{20}$ guaranteed strategic deterrence, so Zapad-13 was concentrating on testing the "Zapad operation" and lasted much longer than officially declared. The already available sizable conventional component allowed terminating military conflicts mostly with conventional troops, so the number of participants in these exercises was greater than announced ${ }^{21}$.

Zapad-13 started in March $\left(11^{\text {th }}-15^{\text {th }}\right)$ as a strategic training event for headquarters and military management structure (стратегическая командноштабная тренировка с центральными органами военного управления и военными округами). During this stage, most probably under the officiallyannounced title of preparation for Zapad, the subsequent stages of the "Zapad

\footnotetext{
${ }^{18}$ А. Гаварский, “Связь решает все”, Красная Звезда, 22052010.

${ }^{19}$ The first Russian State Defense Plan for 2013-2015 was signed by Putin on the $24^{\text {th }}$ of January 2013

${ }^{20}$ Д. Андреев, “Триаду проверили на прочность”, Красная звезда, 22-10-2012.

${ }^{21}$ Officially, around 13,000 troops, 350 tanks, IFVs, APCs, 50 artillery systems, and 50 airframes. After the exercise, in open sources - around 25,000 troops, 550 tanks, IFVs, APC, 100 airframes and 10 ships participated.
} 
operation" were discussed, and time lines and tasks for the involved troops were given ${ }^{22}$.

As it has already been mentioned, most probably, during the official $\mathrm{Za}$ pad-13 in September, emphasis was put on the second stage of the operationexpansion of success and conflict termination by conventional means. A majority of these stage activities took place during the officially-declared Zapad dates in the declared training grounds, while some occurred outside the set time period (for example, exercises of the Northern fleets on September $21^{\text {st }}-25^{\text {th }}$ or the Baltic fleet exercise ${ }^{23}$ ). Conventional forces were already able to fulfill a majority of the tasks assigned to them, so the necessity to emphasize (and demonstrate) the nuclear component (especially tactical) during Zapad-13 was minimal. Only the strategic deterrence element was exercised.

The first "Zapad operation" stage - a sudden attack and capture - was performed by Rapid Reaction Forces which were created on the basis of former air-borne troops. Part of the activities was demonstrated openly during the official Zapad-13, some were hidden under Collective Security Treaty Organization (CSTO) exercise “Cooperation 2013” (“Взаимодействие-2013”) 24. Some first-stage elements were tested months before the official Zapad-13. However, in a majority of cases it was not done to full scale or capacity ${ }^{25}$. One of the major problems not allowing an increase in the scale of the exercise remained. There was still an absence of an adequate C2 system. It was still being created $^{26}$ and only some forces (like the Rapid Reaction Forces) already used automated battle date systems (ABDS) or elements of those systems allowing them to have $\mathrm{C} 2$ and $\mathrm{C} 3$ established between units and different HQs. ${ }^{27}$

The third stage - massive defense involving all state assets - was tested by involving other state institutions (Ministry of the Interior, Ministry of Emergencies, etc.) and trying to run a mobilization of reserve units (most probably, unsuccessfully ${ }^{28}$.

\footnotetext{
22 РИА Новости http://ria.ru/defense_safety/20130311/926661611.html\#ixzz2aVgigbul.

${ }^{23}$ Around 2,500 troops, 30 ships, 50 IFVs APCs and 20 airframes participated.

${ }^{24}$ The eexercise "Vzaimodeistvija-2013" was run in September 2013.

${ }^{25}$ For example, the joint Russian-Belorussian exercise on $22^{\text {nd }}-24^{\text {th }}$ April 2013, at the "Brestkij " training ground, involved units up to a battalion in size.

${ }^{26}$ D. Petraitis, “The New Face of Russia's Military”, Lithuanian Annual Strategic Review, 2014-2015, vol. 13.

${ }^{27}$ An example could be the Rapid Reaction Forces ABMS Andromeda D used in air-borne troops.

${ }^{28}$ After the exercise Zapad-13 General Colonel V. Smirnov, the head of the mobilization unit in the MOD, was fired.
} 


\subsection{Zapad-17}

Zapad-17 took place when the reform was almost complete, the State Defense Plan for 2016-2020 was renewed ${ }^{29}$, an actually-functioning contract soldier system was established, ongoing re-armament was underway, etc. All this strengthened the entire strategic deterrence and allowed General Staff to test first and second "Zapad operation stages" on a much wider scale. It is worth mentioning that some tactical elements of the "Zapad operation" were tested in other strategic exercises which took place before Zapad-17. For example, during the strategic exercise Vostok-14 the strategic movement of troops was tested $^{30}$. A new form of electronic warfare - an electronic strike and blockade of territory by EW means (радиоэлектронный удар и информационное блокирование местности $)^{31}$, a massive air strike ${ }^{3233}$, troops informational warfare $^{34}$, organization of territorial defense ${ }^{35}$, coordination with other forces ${ }^{36}$ - all these elements were tested during Centr-15 and Caucasus-16 exercises.

The appearance of a modern and new C2 system in the troops was an especially important improvement which allowed raising "Zapad operations" testing to a higher level of quality. The improvement included not only developments in ABDS like "Andromeda-D" but also similar ABDSs and new communication equipment (for example, Antey ${ }^{37}$ ) appearing in the troops. As a result, troops were able to establish and maintain reliable and safe communication among HQs a distance thousands of kilometers from one another ${ }^{38}$. It is worth mentioning also that delivery of those ABDSs and new communication

\footnotetext{
${ }^{29}$ An updated Russian Defense Plan for 2016-2020 was signed in November 2015.

30 “Военных с Запада России перебросили авиацией на Дальний Восток для участия в стратегическом командно-штабном учении”, Интерфакс-АВН, Москва 19-09-2014.

31 "Новые формы и способы ведения радиоэлектронной борьбы (РЭБ), будут применены в ходе учения «Центр-2015»”, Минобороны России, Москва, РИА Новости, 15-09-2015.

${ }^{32}$ А. Пинчук, „Массированным ударом „ «Красная звезда». 01-10-2015.

33 “ВС на учениях «Кавказ-2016» отработали авиаудар и борьбу с ракетами”, Москва, РИА Новости, 14092016.

${ }^{34}$ На учениях «Кавказ-2016» впервые отработали «информационное противоборство», Москва, РИА Новости, 14092016.

${ }^{35}$ Р. Голованов, “На «Кавказе» артиллерия и истребители разгромили противника”, Kompravda, 08 09, 2016 http://www.kompravda.eu/daily/26579.4/3594518/.

36 “На учениях «Кавказ-2016» отработали взаимодействие российских силовиков", Полигон Опук (Крым), РИА Новости, 9092016.

37 “Русская армия начала эксплуатацию системы новейшей связи «Антей»", Radioslovo, 2305 2017, http://radioslovo.ru/russkaya-armiya-nachala-ekspluataciyu-sistemy-novejshej-svyazi-antej/.

${ }^{38}$ В. Сирык, “Суперуниверсальный «Антей»: чем уникален радиоцентр для высшего руководства армии”, Zvezda, 2005 2017, https://tvzvezda.ru/news/opk/content/201705200800-o5d9.htm.
} 
equipment to forces increased since $2016^{39}{ }^{40}$ with main delivery going to signal and other units of the JSC "West" in $2017^{41}{ }^{42}$.

All this was enough to have new ABDS and communication systems in both stationary and mobile command posts. The last ones were created for each "Zapad operation" stage testing under the cover of officially-announced signal troops field camps ${ }^{43} 44456$. At the end, every unit participating in the exercise was "plugged in" and became controlled and commanded all the time. During the exercise, the $1^{\text {st }}$ tank Operational Command (OC) even had a new, experimental command post established ${ }^{47}$.

But most importantly, the General Staff, through the National Defense Management Center, concentrated the entire $\mathrm{C} 2$ in its hands. At the same time, the NDMC already had huge computing capabilities allowing it to analyze, design and modify all the different battlefield situations simultaneously ${ }^{48}$.

Again, Zapad-17 was extended in time. It started in January as JSC "West" leadership operative-mobilization training (gathering) (оперативномобилизационные сборы). The event involved around two hundred commanders and staff officers. ${ }^{49}$ According to open sources, new tactical elements (like tactical air lift $)^{50}$ were demonstrated, participants received time-lines for operation stages testing and were ordered to run more than two thousand different tactical training and exercises under the cover of preparation for the

39 “Концерн «Созвездие» поставил Минобороны первые комплексы «Антей»", Интерфакс-Авн, 15052017.

40 “Войска связи $3 В О$ в 2016 году получат 2,5 тысячи единиц новой техники”, Москва, РИА Новости, 0201 2016, http://ria.ru/defense_safety/20160102/1353298275.html\#ixzz3wFoIDOlV.

41 “В войска Западного военного округа (ЗВО) поступили унифицированные командно-штабные машины (УКшМ) P-149MA1” Пресс-служба Западного военного округа, http://function.mil.ru/ news_page/country/more.htm?id=12130927@egNews.

${ }^{42}$ И. Мугинов, “Войска связи 3ВО в 2016 году получат 2,5 тысячи единиц новой техники”, РИА Новости, 0201 2016, http://ria.ru/defense_safety/20160102/1353298275.html\#ixzz3wFoIDOlV.

${ }^{43}$ М. Севастьянов , “Учения ВДВ на северо-западном направлении: длинные руки русского десанта”, РИА Новости, 07072017.

44 “В Западном военном округе проходят учения с соединениями связи”, Пресс-служба

Западного военного округа 3107 2017, http://structure.mil.ru/structure/okruga/west/news/more. htm?id=12135740@egNews.

45 “Более 500 связистов Балтийского флота вышли на учение”, Пресс-служба Западного военного округа , 1508 2017, www.mil.ru.

${ }^{46}$ На учении «Запад-2017» связисты ВДВ обеспечивают пункты управления связью на расстоянии до 2 тыс. Км, 16092017 www.mil.ru.

${ }^{47}$ Н. Сурков, А. Рамм, Е. Дмитриев, “Арматами» будет управлять «штаб звездных войн”, Известия, 20092017.

${ }^{48}$ D. Petraitis, “A New Face of Russian military”, Lithuanian Annual Strategic Review, 2014-2015, vol. 13.

${ }^{49}$ С. Пятаков, “Комсостав ЗВО начал подготовку к учениям «Запад-2017»”, Москва, РИА Новости,

10012017.

50 “В $3 В О$ прошла тренировка по авиапереброске войск на большие расстояния”, пресс-служба ЗВО, Москва, РИА Новости, 12012017. 
official Zapad-1 $7^{51}$. After a few days, a very similar event took place at the strategic level. Here, commanders of all the JSCs, and chiefs of bodies were involved in an overall C3 (a head of NDMC, for example), commanders and chiefs of staffs of OCs also participated. Most probably they also received the same information regarding the exercise, were introduced to new JSC work elements, lessons learned in Syria, some strategic level activities to be tested during the exercise (like the activation and functioning of federal region civil defense HQ in a time of war), etc.

Before the official Zapad-17 took place, forces exercised the first and second "Zapad operation" stages under the cover of planned exercises or activities devoted to prepare for it. A majority of the events happened over the $3^{\text {rd }}-7^{\text {th }}$ of July and $4^{\text {th }}-19^{\text {th }}$ of August. The official Zapad-17 held on September $14^{\text {th }}-20^{\text {th }}$ emphasized the third (massive, state-wide defense) stage and was partially oriented to demonstrate to the West the Russian desire to fight to the end in the event of military conflict.

Zapad-17 was essentially the same as previous exercises but was conducted to a much higher qualitative level. The new security situation required the exercise to be used for strategic messaging again, therefore, as soon as the first two aggressive stages had been exercised; it was in the interests of MOD to demonstrate a defensive stage. Emphasizing transparency and openness as their main motives, the MOD invited journalists and observers from other countries to observe part of the official Zapad.

\subsubsection{Zapad-17. "Zapad operation" first stage}

Let's take a closer look at the Zapad-17 events and try to understand what happened there. A number of indicators (facts) show that a great portion of declared-as-planned activities which happened in the beginning of July $\left(3^{\text {rd }}-7^{\text {th }}\right)$ and almost for the entirety of August $\left(4^{\text {th }}-19^{\text {th }}\right)$ could be taken as "Zapad operation" first and second stage testing. Those activities included not only ordinary units training in the field but also so-called special training (специальная подготовка), command post exercises (командно-штабные тренировки) and field camps (полевые сборы). During both periods, mobile command posts were activated and communication channels were established. Most probably for the first stage, overall C2 (and even C3) was based on the

\footnotetext{
51 “Военнослужащие ЗВО проведут более двух тысяч учений в ходе подготовки к стратегическому учению «Запад-2017”, пресс-службе округа, Москва, Интерфакс-АВН, 17012017.
} 
Andromeda-D system. The second stage used Andromeda-D and next to it, signals units from JSC "West" (three signal brigades and some smaller signal units) established a C3 based on stationary and mobile command posts. Topic and time lines of many activities were obviously coordinated and matched activities to be done in any adequate stage. A majority of participating units were full-flesh units (battalion combat groups) and acted in a joint manner (were supported by aviation, EW, naval, etc.).

The first "Zapad operation" stage training was done under the cover of three officially-announced strategic level command Post Exercises CPXs. Those were: Rapid Reaction Forces CPX, JSC "West" joint military group CPX and JSC "West" air space defense HQs CPX. All CPXs started at about the same time. This is how the course of events was run. Rapid Reaction Force CPX started on the $3^{\text {rd }}-4^{\text {th }} J u l y^{52}$. Units from the $98^{\text {th }}$ air-borne division and the $31^{\text {st }}$ air-borne brigade were alerted ${ }^{53}$. They left permanent locations and started preparations to act: they activated mobile $\mathrm{C} 2$, initiated SOPs for troops and arms parachuting etc. ${ }^{54}$ JSC "West" air space defense units as participants of their own $\mathrm{CPX}^{55}$ were preparing to respond to opponent response (a missive air strike) by EW units training how to hide their own forces and air defense S400 systems preparing to engage targets ${ }^{56}{ }^{57}$. JSC "West" joint military group CPX trained forces how to avoid responding to strikes by maneuvering ${ }^{58}$. July $5^{\text {th }}$ was the day when an assault started. And it started according to the rules of a modern war by precise long range guided munition (PLRGM) strikes to critical opponents' infrastructure first. This was done by two strategic bombers TU-95MS involved in a real combat mission in Syria and firing four air-launched cruise missiles (ALCM) X-101 to weapon arsenals located more than a thousand kilometers away ${ }^{59}$. Alongside bombers, a strategic "Smolensk" submarine in the Barrents Sea fired a cruise missile targeting a "sophisticated na-

\footnotetext{
${ }_{52}$ М. Севастьянов. “Учения ВДВ на северо-западном направлении: длинные руки русского десанта” Полигон Струги Красные (Псковская область , РИА Новости, 07072017.

53 “Более 2 тыс. десантников перебросят в ходе учения к западным границам РФ”, Москва, Интерфакс-АВН, 04072017.

54 “В Псковской области начинается активная фаза учений двух соединений ВДВ”, Москва, РИА Новости, 05072017.

55 “В ЗВО началось КШУ по управлению авиацией и войсками противовоздушной обороны”, Минобороны России, 03072017.

56 “Москва Крылатые ракеты и ударные беспилотники «противника" уничтожают авиация и расчёты ПВО в ходе учений на северо-западе РФ”, Интерфакс-АВН, 03072017

57 “Расчеты комплексов С-400 «Триумф» отразили удар условного противника”, РИА Новости, Москва, 06072017.

58 “Войска ЗВО в ходе учения нанесли массированный ракетно-авиационный удар по позициям условного противника”, Пресс-служба Западного военного округа. 0607 2017, www.mil.ru.

59 “Российские Ту-95МС нанесли ракетный удар по ИГ в Сирии”, Москва, ТАСС, 05072017.
} 
val target" located 400 kilometers away ${ }^{60}$. In reality, this "sophisticated target" might have been ships in a port.

The same day, Baltic Fleet ships left for the sea ${ }^{61}$. Vessels performed safe sea area establishment, air defense, ASW, mining and de-mining ${ }^{62}$, and naval infantry transport ${ }^{63}$ training.

All places foreseen for capture were firstly hit by a massive air strike ${ }^{64}$. The air strikes were imitated by JSC "West"| aviation which exercised live air strikes in training grounds in the Kaliningrad, Pskov and Leningrad regions on the $5^{\text {th }}$ of July ${ }^{65}{ }^{66}$. And right after it, Rapid Reaction Forces started an offense. They were represented by the $31^{\text {st }}$ air-borne brigade and the $98^{\text {th }}$ division which conducted an assault by parachuting troops, equipment and weapons in the "Staryje Strugi" and "Kislov" training grounds and capturing an airfield (Staryje Strugi). Also, they exercised infiltration of diversionary groups in the opponent's rear and, as soon as bridgeheads were captured, entrenching took place $^{67}$.

The same happened in Kaliningrad. Baltic fleet aviation intensified activities in the Baltic Sea air space ${ }^{68}$, provided low-altitude close air support $(\mathrm{CAS})^{69}$ for the $336^{\text {th }}$ naval infantry brigade which in turn conducted a naval infantry landing in Chmeliovka ${ }^{70}$. Sudden assault continued and was expanded. In Pskov, forces holding bridgeheads began receiving reinforcements. On the $6^{\text {th }}$ and $7^{\text {th }} J u l y$, troops from the $76^{\text {th }}$ air-borne division were brought to the captured places by planes and helicopter which landed on the captured Staryje

\footnotetext{
60 “Атомная подлодка «Смоленск» в Баренцевом море поразила учебную цель крылатой ракетой «Гранит» на дальности 400 км - Минобороны РФ”, Москва, Интерфакс-АВН, 05072017.

61 “На Балтике начались учения ВМС", Аргументы Недели, 5072017.

62 “Тральная группа Балтийского флота провела учение по поиску и обезвреживанию мин”, Пресс-служба Западного военного округа, 0607 2017, www.mil.ru.

63 “На Балтийском флоте начинается активная фаза учения разнородных сил”, Пресс-служба Западного военного округа, 05072017.

64 “Войска $3 В О$ в ходе учения нанесли массированный ракетно-авиационный удар по позициям условного противника”, Пресс-служба Западного военного округа, 0607 2017, www.mil.ru. 65 “Авиация 3ВО отработала ракетно-бомбовый удар по войскам условного противника в Ленинградской области”, Пресс-служба Западного военного округа, 0607 2017, www.mil.ru. ${ }^{66} \mathrm{http}: / /$ structure.mil.ru/structure/okruga/west/news/more.htm?id=12132367@egNews.

67 “Под Псковом завершилась основная фаза учения соединений ВДВ”, Департамент информации и массовых коммуникаций Министерства обороны Российской Федерации, 0607 2017, www.mil.ru.

68 “Летчики Балтфлота провели полеты над морем и бомбометание по полигону в

Калининградской области”, Интерфакс-АВН, 06072017.

69 “Летчики Балтфлота провели полеты над морем и бомбометание по полигону в

Калининградской области”, Москва, Интерфакс-АВН, 06072017.

70 “Около 600 военнослужащих и порядка 20 кораблей были задействованы в учении Балтфлота по высадке десанта в Калининградской области”, Москва. Интерфакс-АВН, 07072017.
} 
Strugi airfield ${ }^{71}$. Simultaneously, additional reconnaissance and diversionary groups were parachuted behind opponent lines and started massive diversions and ambushes ${ }^{72}$. The remaining air-borne units exercised penetration and deep raids behind enemy lines in other training grounds in the Pskov region.

General Purpose Forces followed Rapid Reactions Forces and joined the offense. In the training grounds of Leningrad, Nizhniy-Novgorod and Moscow regions, reconnaissance troops from JSC "West" ground force units were running special exercises devoted to offense by small groups and city battle topics $^{73}$. Right after the recce exercises, the main ground forces moved in with moto-riflemen and tank units conducting exercises in the Moscow region. Topics remained the same - fighting in the cities, new types of fire support (tank carousel), marches, combat raids and river crossing, coordination actions with air frames and helicopters. More than 1,500 soldiers, 200 tanks, IFVs and APCs, Su-34 jets and Mi-8 and Mi-24 helicopters were involved ${ }^{74}$. In Kaliningrad, the $11^{\text {th }}$ Army Corp was also involved. The $79^{\text {th }}$ separate motorized riflemen brigade was exercising offense, combat engineer recce and fighting in unknown territories with more than 1,500 soldiers and 200 pieces of weaponry involved ${ }^{75}$.

Offending forces might have met resistance, so to help them, short-range missiles were used. Three missile brigades from JSC "West" armed with Iskander $\mathrm{M}$ and Tochka- $\mathrm{U}$ missiles started their own exercises ${ }^{76}$. At the same time, the fourth missile brigade $\left(448^{\text {th }}\right)$ was conducting a live missile launch in the Kapustin Jar firing range next to Astrakhan ${ }^{77}$. Simultaneously, to mislead and not allow opponent Air Force striking advancing troops, EW (Krasucha 2/4) and Air defense (S400) units exercised defense against a massive air strike.

Summing up all these activities, one feature does stand out - a sudden

\footnotetext{
${ }^{71}$ М. Севастьянов, “Учения ВДВ на северо-западном направлении: длинные руки русского десанта”, Полигон Струги Красные (Псковская область), РИА Новости, 07072017.

72 “Две с половиной тысячи десантников проводят учение в Псковской области”, Псковская обл,.

“Интерфакс-АВН”, 05072017.

73 “Войсковые разведчики $3 В О$ отработают захват и уничтожение штабов и органов военного управления условного противника”, Пресс-служба Западного военного округа, 08072017 , www.mil.ru.

74 “Российские военные под Нижним Новгородом учатся брать города с применением «танковой карусели»", Москва. Интерфакс-АВН, 07072017.

75 “Армейский корпус Балтийского флота приступил к завершающему этапу боевой учебы, более 1,5 тыс. военных балтийцев из соединений и частей 11 армейского корпуса Балтийского флота отрабатывают навыки ведения боя”, Интерфакс, 08072017.

${ }^{76} \mathrm{C}$ расчетами «Искандер-М» и «Точка-У» ЗВО проведена тренировка по управлению ракетными ударами“, Интерфакс, 08072017.

77 “Курские ракетчики провели учебно-боевые пуски ракет «Точка» в Астраханской области”, Москва, Интерфакс-АВН, 10072017
} 
attack was performed in every location. The offense was supported from the air, sea, and land; at long distances and close ranges; involving PGLRMs, EW and air defense. The number of participants and weaponry involved in the mentioned activities alone (see Table 1) rounded up to more than 14,000 soldiers, 1,000 pieces of different weaponry, 3,000 pieces of other military equipment, around 70 air frames and helicopters and 20 ships. All the activities were controlled and coordinated from the NDMC with the involvement of Andromeda- ${ }^{78}$ and other systems. It is worth mentioning that a number of other military exercises and activities took place at the same time in other Russian territories as well. Theoretically, they might be assigned to the first stage as well, but more information and data is needed before a more reliable statement can be made.

Table 1. Zapad, 2017 July, likely $1^{\text {st }}$ stage "Sudden Attack/Capture"

\begin{tabular}{|c|c|c|c|c|c|}
\hline $\begin{array}{l}\text { Date } \\
2017 \\
\text { JULY }\end{array}$ & JSC & Unit/Location & Size* & Action & Remarks \\
\hline $\begin{array}{l}\text { JULY } \\
3-5\end{array}$ & JCS RRF & $\begin{array}{l}\text { Air-borne troops } \\
\text { 98th D,76th D 31st B } \\
\text { Transport avia, } \\
\text { Pskov }\end{array}$ & $?$ & $\begin{array}{l}\text { Offense, Alarmed, } \\
\text { leaving garrisons } \\
\text { to boarding sites, } \\
\text { preparing for action, } \\
\text { establishing C2 }\end{array}$ & $\begin{array}{l}\text { Officially not } \\
\text { Zapad, synchro- } \\
\text { nized, match- } \\
\text { ing actions }\end{array}$ \\
\hline $\begin{array}{l}\text { JULY } \\
5\end{array}$ & JSC Nuclear & $\begin{array}{l}\text { Northern Fleet } \\
\text { Submarine Forces } \\
\text { Barents Sea }\end{array}$ & $\begin{array}{l}+-100 S \\
1 \mathrm{SM}\end{array}$ & $\begin{array}{l}\text { Offense, Nuclear } \\
\text { Submarine "Smolensk" } \\
\text { launching SLCM } \\
\text { "Granit" against so- } \\
\text { phisticated naval target } \\
\text { (distance } 400 \mathrm{~km} \text { ) }\end{array}$ & $\begin{array}{l}\text { Officially not } \\
\text { Zapad, synchro- } \\
\text { nized, match- } \\
\text { ing actions }\end{array}$ \\
\hline $\begin{array}{l}\text { JULY } \\
5\end{array}$ & JSC Nuclear & $\begin{array}{l}\text { Start aviation OC } \\
\text { Strat bombers } \\
\text { Syria }\end{array}$ & $\begin{array}{l}? \mathrm{~S} \\
2 \mathrm{Ai}\end{array}$ & $\begin{array}{l}\text { Offense, } 2 \text { Tu 95MSM } \\
\text { bombers launching } 4 \\
\text { ALCM X-101 to targets } \\
\text { in Syria }\end{array}$ & $\begin{array}{l}\text { Officially not } \\
\text { Zapad, synchro- } \\
\text { nized, matching } \\
\text { actions }\end{array}$ \\
\hline $\begin{array}{l}\text { JULY } \\
5\end{array}$ & JSC West & $\begin{array}{l}\text { Three MsBs } \\
\text { Moscow } \\
\text { Leningrad/Kursk }\end{array}$ & $\begin{array}{l}+-500 \mathrm{~S} \\
200 \mathrm{ME}\end{array}$ & $\begin{array}{l}\text { Offense, Coordina- } \\
\text { tion of missile strike, } \\
\text { electronic launches }\end{array}$ & $\begin{array}{l}\text { Officially not } \\
\text { Zapad, synchro- } \\
\text { nized, matching } \\
\text { actions }\end{array}$ \\
\hline $\begin{array}{l}\text { JULY } \\
5\end{array}$ & JSC West & $\begin{array}{l}\text { X? ABC unit } \\
\text { Leningrad }\end{array}$ & $?$ & $\begin{array}{l}\text { Offense/defense, } \\
\text { Aerosol Camouflage of } \\
\text { Iskander missiles }\end{array}$ & $\begin{array}{l}\text { Officially not } \\
\text { Zapad, synchro- } \\
\text { nized, matching } \\
\text { actions }\end{array}$ \\
\hline $\begin{array}{l}\text { JULY } \\
6\end{array}$ & JSC West & $\begin{array}{l}\text { AAD units, } \\
\text { District wide }\end{array}$ & $\begin{array}{l}+5000 \mathrm{~S} \\
+2000 \mathrm{ME}\end{array}$ & $\begin{array}{l}\text { Offense, Area AAD, } \\
\text { AtoA fighting training, } \\
\text { S } 400 \text { training, }\end{array}$ & $\begin{array}{l}\text { Officially not } \\
\text { Zapad, synchro- } \\
\text { nized, matching } \\
\text { actions }\end{array}$ \\
\hline
\end{tabular}

\footnotetext{
78 “Учения ВДВ на северо-западном направлении: длинные руки русского десанта”, 07072017 , https://ria.ru/defense_safety/20170707/1498098871.html.
} 


\begin{tabular}{|c|c|c|c|c|c|}
\hline $\begin{array}{l}\text { JULY } \\
6\end{array}$ & JSC West & $\begin{array}{l}\text { EW units from } \\
\text { Moscow, } \\
\text { Nizhniy Novgorod, } \\
\text { Kaliningrad, Kursk }\end{array}$ & $\begin{array}{l}+-150 \mathrm{~S} \\
20 \mathrm{ME}\end{array}$ & $\begin{array}{l}\text { Offense, EW units } \\
\text { measures to protect } \\
\text { troops, SIGINT }\end{array}$ & $\begin{array}{l}\text { Officially not } \\
\text { Zapad, synchro- } \\
\text { nized, matching } \\
\text { actions }\end{array}$ \\
\hline $\begin{array}{l}\text { JULY } \\
6\end{array}$ & JSC West & $\begin{array}{l}\text { 448th MsB } \\
\text { Astrakhan }\end{array}$ & $\begin{array}{l}+-500 \mathrm{~S} \\
100 \mathrm{ME}\end{array}$ & $\begin{array}{l}\text { Offense, Launch of } \\
\text { Tochka U missile in } \\
\text { Kopustin Jar shooting } \\
\text { range }\end{array}$ & $\begin{array}{l}\text { Officially not } \\
\text { Zapad, synchro- } \\
\text { nized, match- } \\
\text { ing actions }\end{array}$ \\
\hline $\begin{array}{l}\text { JULY } \\
5-7\end{array}$ & JCS RRF & $\begin{array}{l}\text { Air-borne troops } \\
\text { 98thD,76thD 31st B } \\
\text { Transport aviation } \\
\text { Pskov }\end{array}$ & $\begin{array}{l}+-2500 \mathrm{~S} \\
500 \mathrm{ME} \\
40 \mathrm{Air} \\
\text { and } \mathrm{H}\end{array}$ & $\begin{array}{l}\text { Offense, Alarmed, air } \\
\text { transport, air assault, } \\
\text { capture of bridge- } \\
\text { heads, reinforcements } \\
\text { by air and land, diver- } \\
\text { sions in the rear }\end{array}$ & $\begin{array}{l}\text { Officially not } \\
\text { Zapad, synchro- } \\
\text { nized, match- } \\
\text { ing actions }\end{array}$ \\
\hline $\begin{array}{l}\text { JULY } \\
6\end{array}$ & JSC RRF & $\begin{array}{l}\text { 336th NIB. BF } \\
\text { aviation } \\
\text { Kaliningrad }\end{array}$ & $\begin{array}{l}+600 \mathrm{~S} \\
15 \mathrm{ME}\end{array}$ & $\begin{array}{l}\text { Offense, Capture of } \\
\text { bridgehead on the } \\
\text { coast. Naval landing }\end{array}$ & $\begin{array}{l}\text { Officially not } \\
\text { Zapad, synchro- } \\
\text { nized, matching } \\
\text { actions }\end{array}$ \\
\hline $\begin{array}{l}\text { JULY } \\
6\end{array}$ & JSC West & $\begin{array}{l}\text { Baltic Fleet, } \\
\text { Baltic Sea/ } \\
\text { Kaliningrad }\end{array}$ & $\begin{array}{l}+ \\
1000 S \\
20 \mathrm{SS}\end{array}$ & $\begin{array}{l}\text { Offense/Defense Mine } \\
\text { sweeping, protection } \\
\text { of ships on-route, sea } \\
\text { mining, transport of } \\
\mathrm{NI} \text {, fire support from } \\
\text { the sea to amphibious } \\
\text { landing }\end{array}$ & $\begin{array}{l}\text { Officially not } \\
\text { Zapad, synchro- } \\
\text { nized, matching } \\
\text { actions }\end{array}$ \\
\hline $\begin{array}{l}\text { JULY } \\
6\end{array}$ & JSC West & $\begin{array}{l}\text { Baltic Fleet, } \\
\text { Aviation unit } \\
\text { Kaliningrad }\end{array}$ & $\begin{array}{l}\text { ? S } \\
10 \mathrm{Ai} \\
\text { and } \mathrm{H}\end{array}$ & $\begin{array}{l}\text { Offense, Massive air } \\
\text { strike, Assistance to } \\
\text { amphibious assault }\end{array}$ & $\begin{array}{l}\text { Officially not } \\
\text { Zapad, synchro- } \\
\text { nized, matching } \\
\text { actions }\end{array}$ \\
\hline $\begin{array}{l}\text { JULY } \\
6\end{array}$ & JSC West & $\begin{array}{l}\text { 6th Air OC, } \\
\text { Aviation units } \\
\text { Leningrad }\end{array}$ & $\begin{array}{l}\text { ? S } \\
10 ? \mathrm{Ai} \\
\text { and } \mathrm{H}\end{array}$ & $\begin{array}{l}\text { Offense, Massive air } \\
\text { strike, Assistance to } \\
\text { amphibious assault }\end{array}$ & $\begin{array}{l}\text { Officially not } \\
\text { Zapad, synchro- } \\
\text { nized, matching } \\
\text { actions }\end{array}$ \\
\hline $\begin{array}{l}\text { JULY } \\
6\end{array}$ & JSC West & $\begin{array}{l}\text { X? OC } \\
\text { X? MR } \\
\text { Nizhniy Novgorod }\end{array}$ & $\begin{array}{l}+-1300 \mathrm{~S} \\
250 \mathrm{ME} \\
10 ? \mathrm{Ai} \\
\text { and } \mathrm{H}\end{array}$ & $\begin{array}{l}\text { Offense, Regimentals } \\
\text { TG in offense, river } \\
\text { crossing, battle in the } \\
\text { cities, new tactics "tank } \\
\text { carousel" }\end{array}$ & $\begin{array}{l}\text { Officially not } \\
\text { Zapad, synchro- } \\
\text { nized, matching } \\
\text { actions }\end{array}$ \\
\hline $\begin{array}{l}\text { JULY } \\
6\end{array}$ & JSC West & $\begin{array}{l}\text { X? OC } \\
\text { RECCE units } \\
\text { Nizhniy Novgorod, } \\
\text { Moscow, Leningrad }\end{array}$ & $\begin{array}{l}+-1000 \mathrm{~S} \\
200 \mathrm{ME}\end{array}$ & $\begin{array}{l}\text { Offense, Training on } \\
\text { fighting in the cities, } \\
\text { capture of objects, } \\
\text { diversions of foe HQs } \\
\text { and C2 nots }\end{array}$ & $\begin{array}{l}\text { Officially not } \\
\text { Zapad, synchro- } \\
\text { nized, matching } \\
\text { actions }\end{array}$ \\
\hline $\begin{array}{l}\text { JULY } \\
7\end{array}$ & JSC West & $\begin{array}{l}\text { 11th Corp, } \\
\text { X? Motorifle units } \\
\text { Kaliningrad }\end{array}$ & $\begin{array}{l}+-1500 \mathrm{~S} \\
200 \mathrm{ME}\end{array}$ & $\begin{array}{l}\text { Offense, Fighting in } \\
\text { offense, marches, } \\
\text { capture of objects }\end{array}$ & $\begin{array}{l}\text { Officially not } \\
\text { Zapad, synchro- } \\
\text { nized, matching } \\
\text { actions }\end{array}$ \\
\hline $\begin{array}{l}\text { TO- } \\
\text { TAL }\end{array}$ & & & $\begin{array}{l}-+14000 \mathrm{~S} \\
+-3600 \mathrm{ME} \\
-+70 \mathrm{Ai} \\
+-20 \mathrm{SS} \\
1 \mathrm{SM}\end{array}$ & & \\
\hline
\end{tabular}

Legend: JSC - joint strategic command, OC - operational command, B- brigade, R- regiment, MD - moto-rifle division, TD - tank division, NIB - naval infantry brigade, CDB - coastal defense brigade, $\mathrm{S}$ - soldiers/sailors, ME - military equipment (Combat plus other), $\mathrm{SH}$ - surface ships: $\mathrm{SS}$ - surface ships; SM - submarines; SA - auxiliary ships A - air frames; Ai - aircrafts. H - Helicopters 


\subsubsection{Zapad-17. "Zapad operation" second stage}

Exercising the second "Zapad operation" stage - safeguarding and extending achievements and stabilization/termination of the conflict - took place in August (probable dates $7^{\text {th }}-23^{\text {rd }}$ ). During that period, a number of two-sided exercises or announced-as-planned military activities, at first glance unrelated to one another, took place in JSC "West". Again, Rapid Reaction and General Purpose forces worked in a highly synchronized manner. JSC "West" signal units started a district level signal exercise on the $13^{\text {th }}-14^{\text {th }}$ August ${ }^{79}$. Participants were the $1^{\text {st }}$ JSC command/control brigade, the $132^{\text {nd }}$ territorial signal brigade and the $9^{\text {th }}$ signal brigade from the $20^{\text {th }}$ operational command. Altogether, there were around 4,000 solders, 1,000 pieces of different equipment ${ }^{80}$. They were joined by signal units from the Baltic Fleet ${ }^{81}{ }^{82}$ and the $38^{\text {th }}$ air-borne troops signal brigade ${ }^{83}$. During the exercise, an actually-functioning C3 consisting of around fifty mobile command posts ${ }^{84}$ and involving units from a company to strategic HQ level was created. As a result, all different exercises participants became plugged in to one overall C3.

This stage, like the first one, was again started by Rapid Reaction Forces. On the $8^{\text {th }}-11^{\text {th }}$ of August air-borne troops and naval infantry launched twosided exercises in the Pskov and Kaliningrad regions. In Pskov, it was called a demonstrative two-sided regimental exercise. The exercise topic was a regiment in offense. Here, one battalion tactical group (BTG) was parachuted with combat vehicles and captured an airfield, the second BTG was delivered to the captured airfield by helicopters and the third one made a combat march on land while crossing a river and joining another two battalions ${ }^{85}$. All the offending forces had fire support from their own artillery and bombers and helicopters coming from the Army aviation. The exercise involved the $76^{\text {th }}$ and

\footnotetext{
79 “В ЗВО проведены тактико-специальные учения одновременно с тремя соединениями связи”, Пресс-служба Западного военного округа. 0708 2017, www.mil.ru.

80 “В Западном военном округе проходят учения с соединениями связи”, Пресс-служба Западного военного округа, 31072017.

81 “Более 500 связистов Балтийского флота вышли на учение”, Пресс-служба Западного военного округа, 1508 2017, www.mil.ru.

82 “Связисты Балтфлота испытают на учениях современные средства связи”, КАЛИНИНГРАД, РИА Новости, 15082017.

83 "ВДВ России в ходе пятидневных учений в СЗФО отработают весь спектр задач войск на период военного времени”, Интерфакс-АВН, 07082017.

84 “В Западном военном округе проходят учения с соединениями связи”, Пресс-служба Западного военного округа, 31072017.

85 “ВДВ России в ходе пятидневных учений в СЗФО отработают весь спектр задач войск на период военного времени”, Интерфакс-АВН, 07082017.
} 
$106^{\text {th }}$ air-borne divisions, the $31^{\text {st }}$ and $45^{\text {th }}$ air-borne brigades and the $38^{\text {th }}$ airborne signal brigade. The participants of all those events were more than 2,500 soldiers, around 600 pieces of weaponry and few dozen jets and helicopters ${ }^{86}$ 87888990 . At the same time, ( $9^{\text {th }}$ August) the $336^{\text {th }}$ naval infantry brigade and the $7^{\text {th }}$ moto-rifleman regiment started a two-sided exercise in the Chmeliovka training ground (Kaliningrad). Here, around 500 marines, supported from the air ${ }^{91}$, tried to capture a bridgehead which was defended by motorized infantry ${ }^{92}$. In total, more than 2,000 soldiers, around 100 pieces of weaponry, 20 ships and 12 air frames were involved. Alongside this, the Baltic Fleet ${ }^{93}$ and its aviation units ${ }^{94}$ conducted, announced as separate, exercises on fire and close air support (CAS). Combat engineers ${ }^{96}$ and $\mathrm{EW}^{97}$ units were involved in this venture also.

A fight for captured areas continued. Now land forces employed additional air and coastal defense. The same day ( $9^{\text {th }}$ August), in the Kaliningrad region, the local coastal defense brigade performed live firing from "Bal" and "Bastion" systems" and air defense S300 systems withstood a massive oppo-

\footnotetext{
86 “Батальон ВДВ при поддержке авиации отбил у «боевиков» аэродром под Псковом”, Москва, TACC, 0908 2017, http://tass.ru/armiya-i-opk/4471921.

87 "ВДВ России в ходе пятидневных учений в СЗФО отработают весь спектр задач войск на период военного времени”, Интерфакс-АВН, 07082017.

88 "Новое оборудование для прыжков с большой высоты испытали в ходе учений ВДВ под

Псковом", Псков, ТАCС, 0908 2017, http://tass.ru/armiya-i-opk/4472182.

89 “Десантники в ходе учений под Псковом ликвидировали лагерь условного НВФ, Струги Красные (Псковская область), Интерфакс-АВН, 1008 2017, www.militarynews.ru.

90 “В полковых учениях ВДВ в Псковской области задействовано около 40 самолетов и вертолетов Минобороны РФ”, Псков. Интерфакс-АВН, 08082017.

${ }^{91}$ Масштабное учение морской пехоты Балтийского флота прошло в Калининградской области, Пресс-служба Западного военного округа. 1008 2017, www.mil.ru.

92 “Морские пехотинцы Балтийского флота на учении в Калининградской области отрабатывают вопросы обороны побережья”, Пресс-служба Западного военного округа, 1608 2017, www.mil.ru.

93 “Около 20 боевых кораблей и судов обеспечения Балтийского флота принимают участие в командно-штабной тренировке”, Пресс-служба Западного военного округа. 1508 2017, www.mil.ru. 94 “Летчики Балтийского флота проводят практические ракетные стрельбы под Калининградом", Калининград, ТАСС,14 08 2017, http://tass.ru/armiya-i-opk/4481305.

95 "Морская авиация БФ поддержала высадку морского десанта на учении в Калининградской области", .Пресс-служба Западного военного округа. 1708 2017, www.mil.ru.

96 “Инженеры Балтийского флота провели тактико-специальное учение”, пресс-служба ЗВО по Балтийскому флоту, 1008 2017, https://yaostrov.ru/corps/ucheniya/item/52302-инженерыбалтийского-флота-провели-тактико-специальное-учение\#ixzz4qSNyoQqt.

97 “Подразделение РЭБ Балтийского флота подавило систему связи условного противника в ходе учения", Пресс-служба Западного военного округа. 1108 2017, www.mil.ru.

${ }_{98}$ С. Песоцкая, “«Бал» и «Бастион» уничтожили корабли «противника» на Балтике”, Российская газета, 0908 2017, https://rg.ru/2017/08/09/reg-szfo/raketchiki-baltflota-unichtozhili-korabli-uslovnogoprotivnika.html.
} 
nents' air strike ${ }^{99}$. Simultaneously, there was another two-sided exercise between the already-mentioned $336^{\text {th }}$ naval infantry brigade and the $79^{\text {th }}$ motorized infantry brigade ( $11^{\text {th }}$ Army Cops, Kaliningrad). Here, everything was done in opposite - naval infantry defended an area and infantry tried to recapture it. Around 700 soldiers and 40 combat vehicles were involved here ${ }^{100}$. On the $11^{\text {th }}$ of August, motorized riflemen from the $11^{\text {th }}$ Corps ${ }^{101} 102$ units received support from EW unit belonging to the $79^{\text {th }}$ motorized infantry brigade. Around 100 soldiers and 20 pieces of equipment ${ }^{103}$ had an exercise on blocking enemy communication ${ }^{104}$ and protecting their own forces against air strikes. Defense of captured territories and entrenchment exercises continued everywhere with aviation $^{105}$, artiller $\mathrm{y}^{106}$, EW means were intensively used. The geography of these exercises was widened. The $20^{\text {th }}$ OC from JSC "West" started a two-sided exercise between two newly formed divisions $\left(3^{\text {rd }}\right.$ and $\left.114^{\text {th }}\right)$. Officially it was announced as a certification exercise and units from both divisions performed offense, defense, regrouping, receiving supplies after a battle ${ }^{107} 108109$, but this was exactly what they would be doing if involved in the second stage of a " $\mathrm{Za}$ pad operation". The same activities (offense, defense, regrouping, etc.) were

\footnotetext{
99 „Комплексы С-300 сбили «нарушителей» границы над Калининградом“, Российская газета, 1108 2017, https://rg.ru/2017/08/11/reg-szfo/kompleksy-s-300-sbili-narushitelej-granicy-nadkaliningradom.html.

${ }^{100}$ Мотострелки Балтийского флота уничтожат морской десант условного противника в ходе учения, Пресс-служба Западного военного округа. 1408 2017, www.mil.ru.

101 "В Калининградской области проходит тактическое учение мотострелкового соединения армейского корпуса”, пресс-службы ЗВО по Балтийскому флоту, 08 08, 2017: https://yaostrov. ru/corps/ucheniya/item/52296-в-калининградской-области-проходит-тактическое-учениемотострелкового-соединения-армейского-корпуса\#іxzz4qSP6QSbu.

102 “Полковое учение армейского корпуса началось в Калининградской области”, пресс-служба 3ВО по Балтийскому флоту, 1408 2017, https://yaostrov.ru/corps/ucheniya/item/52306-полковое-учениеармейского-корпуса-началось-в-калининградской-области\#іxzz4qSNLnRzE.

103 “Под Калининградом начались учения мотострелков Балтфлота”, пресс-службы Балтийского флота, 0808 2017, https://rg.ru/2017/08/08/reg-szfo/pod-kaliningradom-nachalis-takticheskoe-ucheniemotostrelkov-baltflota.html.

104 “Подразделение РЭБ Балтийского флота подавило систему связи условного противника в ходе учения”, Пресс-служба Западного военного округа. 1108 2017, www.mil.ru.

105 “Авиаудары и высадка десанта на учениях морской пехоты Балтийского флота", 1908 2017, https://ria.ru/video/20170819/1500688024.html.

106 “Артиллеристы БФ провели учебно-боевые стрельбы с использованием беспилотников", пресс-служба ЗВО по Балтийскому флоту, 0408 2017, https://yaostrov.ru/corps/ucheniya/ item/52293-артиллеристы-бф-провели-учебно-боевые-стрельбы-с-использованиембеспилотников\#іxzz4qSPdgZbp.

107 “Более 2000 человек и 600 единиц техники поднято по тревоге в рамках двустороннего учения в Воронежской области”, Пресс-служба Западного военного округа. 1708 2017, www.mil.ru.

108 “На учениях под Воронежем артиллеристы уничтожили базы «противника", Москва, РИА Новости, 20082017.

109 “Подразделение МТО на учении в Воронежской области обеспечит дозаправку топливом боевых машин в полевых условиях”. Пресс-служба Западного военного округа. 1508 2017, www.mil.ru.
} 
seen in training fields located in the Moscow, Nizhniy-Novgorod and Smolensk regions ${ }^{110}$, where the $1^{\text {st }}$ tank OC had own exercises. Again, artillery ${ }^{111}$, aviation and EW means ${ }^{112}$ were used intensively ${ }^{113}{ }^{114}$. In the Leningrad region, the $138^{\text {th }}$ motorized infantry brigade belonging to the $6^{\text {th }}$ OC from JSC "West" was also running similar training ${ }^{115} 116117$.

With the end of the stage approaching, pressure on the opponent had increased. JSC "Nuclear forces" joined the game by starting the so-called planned exercise. Eleven strategic missile regiments spread in the combat patrols exercising in Russia, withstanding opponents' SOF attempts to destroy missiles $^{118}$ and imitating missile launches ${ }^{119}$. Naval and air components of JSC "Nuclear Forces" were also involved - the submarine "Severodvinsk" did live firing with "Caliber" cruise missiles ${ }^{120}$ and strategic bombers accompanied by jets flew a patrol mission in the Pacific ${ }^{121}$.

When summarizing all the mentioned activities, one can see that everywhere a wide scale offense was carried out with the tasks to defend captured areas, to extend success and in the final stages, to get nuclear forces involved to force the opponent to reconsider fighting and move on to the negotiation table. All unit actions on land received widespread air support, LRPGMs were

\footnotetext{
110 “В ЗВО по учебной тревоге подняли части Первой танковой армии”, С.-Петербург, РИА Новости, 1508 2017, https://ria.ru/defense_safety/20170815/1500382408.html.

111 “Артиллеристы Таманской мотострелковой дивизии ЗВО отработают ведение высокоточной стрельбы”, Пресс-служба Западного военного округа. 2908 2017, www.mil.ru.

112 “Артиллеристы 3ВО впервые применят новейшую модификацию «Мсты-С» на стрельбах под Нижним Новгородом”, Пресс-служба Западного военного округа. 1908 2017, www.mil.ru.

113 “Расчеты РЭБ Западного военного округа подавили систему связи условного противника в Тамбовской области”, Пресс-служба Западного военного округа. 2808 2017, www.mil.ru.

114 “Соединение РЭБ ЗВО поднято по тревоге на учение и совершает марш на незнакомый полигон в Тамбовской области”,17 08 2017, http://function.mil.ru/news_page/country/more.htm?id=12138061@ egNews.

115 “Более 1000 военнослужащих ЗВО участвует в двухстороннем БТУ под Санкт-Петербургом", Пресс-служба Западного военного округа. 1708 2017, www.mil.ru.

116 “Ударный батальон мотострелкового соединения ЗВО зажал «противника» в «огневом мешке”, Пресс-служба Западного военного округа. 0309 2017, www.mil.ru.

117 “Тюльпаны» и «Пионы» уничтожили заглубленные командные пункты условного противника в Ленинградской области”, Пресс-служба Западного военного округа. 2908 2017, www.mil.ru. 118 “ПГРК «Тополь», «Тополь-М» и «Ярс» отрабатывают манёвренные действия на маршрутах боевого патрулирования в четырёх регионах России”, Департамент информации и массовых коммуникаций Министерства обороны Российской Федерации. 1508 2017, www.mil.ru.

119 “Ракетчики проведут условные пуски из «Тополя» в Тверской области”, Москва, ТАСС,

1708 2017, http://tass.ru/armiya-i-opk/4488075.

120 “Подлодка в Баренцевом море провела стрельбу крылатой ракетой «Калибр»", Пресс-служба Северного флота, 1808 2017, https://iz.ru/634257/2017-08-18/podlodka-v-barentcevom-more-provelastrelbu-krylatoi-raketoi-kalibr.

121 “Ракетоносцы ВКС выполнили полеты над нейтральными водами в Тихом океане”, Москва, РИА Новости, 24082017.
} 
used and air space control and territorial air defense was implemented. More than 27,000 soldiers, around 4,200 combat and other equipment, 50 air frames and 20 ships might have been involved in all the activities mentioned above (see Table 2). And again, a number of other military exercises and activities, which might be assigned to the second stage, took place in different Russian locations, but to be confident about this, more information and data is needed.

\section{Table 2. Zapad, 2017 August, likely the $2^{\text {nd }}$ stage “Expend and Reinforcement} of the Success"

\begin{tabular}{|c|c|c|c|c|c|}
\hline Date & JSC & Unit/ Location & Size* & Action & Remarks \\
\hline $\begin{array}{l}\text { July } 31 \\
\text { Aug? }\end{array}$ & JSC West & $\begin{array}{l}3 \text { Signal Br } \\
\text { Nizhniy Novgorod, } \\
\text { S Petersburg } \\
\text { Voronezh, } \\
\text { Kaliningrad }\end{array}$ & $\begin{array}{l}+-5000 \mathrm{~S} \\
1000 \mathrm{ME}\end{array}$ & $\begin{array}{l}\text { Establish and maintaining } \\
\text { overall C2 }\end{array}$ & $\begin{array}{l}\text { Officially not } \\
\text { Zapad, synchro- } \\
\text { nized, matching } \\
\text { actions }\end{array}$ \\
\hline Aug 4 & JSC West & $\begin{array}{l}\text { 11th Corp, 7th MR } \\
\text { Kaliningrad }\end{array}$ & $\begin{array}{l}+-500 \mathrm{~S} \\
65 \mathrm{ME}\end{array}$ & $\begin{array}{l}\text { Defense against amphib- } \\
\text { ian landing (EW, Artillery } \\
\text { support) }\end{array}$ & $\begin{array}{l}\text { Officially not } \\
\text { Zapad, synchro- } \\
\text { nized, matching } \\
\text { actions }\end{array}$ \\
\hline $\begin{array}{l}\text { Aug } \\
8-11\end{array}$ & $\begin{array}{l}\text { JSC RRF } \\
\text { JSC West }\end{array}$ & Transport Avia OC & $\begin{array}{l}? S \\
40\end{array}$ & $\begin{array}{l}\text { Offense to support RRF } \\
\text { Air-borne troops EX }\end{array}$ & $\begin{array}{l}\text { Officially not } \\
\text { Zapad, synchro- } \\
\text { nized, matching } \\
\text { actions }\end{array}$ \\
\hline $\begin{array}{l}\text { Aug } \\
8-11\end{array}$ & JSC RRF & $\begin{array}{l}\text { 76thD, 31stB, } \\
\text { 45thB, 106thD } \\
\text { Pskov }\end{array}$ & $\begin{array}{l}+2500 S \\
+600\end{array}$ & $\begin{array}{l}\text { Offense regiment } \\
\text { exercise } \\
\text { air assault, capture of } \\
\text { airfield, reinforcement by } \\
\text { air, raids in opponent rear }\end{array}$ & $\begin{array}{l}\text { Officially not } \\
\text { Zapad, synchro- } \\
\text { nized, matching } \\
\text { actions }\end{array}$ \\
\hline Aug 8 & $\begin{array}{l}\text { JSC } \\
\text { West, }\end{array}$ & $\begin{array}{l}\text { 11th Corp, } \\
\text { 79th MB } \\
\text { Kaliningrad }\end{array}$ & $\begin{array}{l}+700 \mathrm{~S} \\
40 \mathrm{ME} \\
+4^{*}\end{array}$ & $\begin{array}{l}\text { Offense BTG training } \\
\text { with artillery and CAS }\end{array}$ & $\begin{array}{l}\text { Officially not } \\
\text { Zapad, synchro- } \\
\text { nized, matching } \\
\text { actions }\end{array}$ \\
\hline Aug 9 & $\begin{array}{l}\text { JSC } \\
\text { West, }\end{array}$ & $\begin{array}{l}\text { 11th Corp, } \\
\text { 25th CDB } \\
\text { Kaliningrad, }\end{array}$ & $\begin{array}{l}+-200 * \mathrm{~S} \\
+-10 * \mathrm{ME}\end{array}$ & $\begin{array}{l}\text { Offense/Defense. En- } \\
\text { gage approaching ships }\end{array}$ & $\begin{array}{l}\text { Officially not } \\
\text { Zapad, synchro- } \\
\text { nized, matching } \\
\text { actions }\end{array}$ \\
\hline Aug 9 & JSC RRF, & $\begin{array}{l}\text { 336th NIB } \\
\text { Kaliningrad }\end{array}$ & $\begin{array}{l}+-500 \mathrm{~S} \\
40 \mathrm{ME}\end{array}$ & $\begin{array}{l}\text { Offense Naval landing } \\
\text { (battalion) Fire support } \\
\text { from ships }\end{array}$ & $\begin{array}{l}\text { Officially not } \\
\text { Zapad, synchro- } \\
\text { nized, matching } \\
\text { actions }\end{array}$ \\
\hline Aug 10 & JSC West & $\begin{array}{l}\text { BF, } \\
\text { Naval Engineer R, } \\
\text { Kaliningrad }\end{array}$ & $\begin{array}{l}+-150 \mathrm{~S} \\
20 \mathrm{ME}\end{array}$ & $\begin{array}{l}\text { Offense Demining, mine } \\
\text { clearing potential landing } \\
\text { zones }\end{array}$ & $\begin{array}{l}\text { Officially not } \\
\text { Zapad, synchro- } \\
\text { nized, matching } \\
\text { actions }\end{array}$ \\
\hline $\begin{array}{l}\text { Aug } \\
10-16\end{array}$ & JSC West & $\begin{array}{l}\text { 11th Corp +NI } \\
\text { 7th MR+336th } \\
\text { NIB, Kaliningrad }\end{array}$ & $\begin{array}{l}+-2000 \mathrm{~S} \\
100 \mathrm{ME} \\
12 \mathrm{Ai} \\
20 \mathrm{SS}\end{array}$ & $\begin{array}{l}\text { Offense/Defense Two- } \\
\text { sided exercise 336th NIB } \\
\text { landing, 7th MR coast } \\
\text { defense, artillery and } \\
\text { CAS involved }\end{array}$ & $\begin{array}{l}\text { Officially not } \\
\text { Zapad, synchro- } \\
\text { nized, matching } \\
\text { actions }\end{array}$ \\
\hline
\end{tabular}




\begin{tabular}{|c|c|c|c|c|c|}
\hline Aug 11 & JSC West & $\begin{array}{l}\text { 11th Corp EW } \\
\text { units } \\
\text { Kaliningrad }\end{array}$ & $\begin{array}{l}+-100 S \\
20\end{array}$ & $\begin{array}{l}\text { Possibly part of a two- } \\
\text { sided exercise from Aug } \\
\text { 10. Jamming, SIGINT, } \\
\text { EW protection of moving } \\
\text { troops }\end{array}$ & $\begin{array}{l}\text { Officially not } \\
\text { Zapad, synchro- } \\
\text { nized, matching } \\
\text { actions }\end{array}$ \\
\hline Aug 11 & JSC West & $\begin{array}{l}11 \text { th Corp AAD } \\
\text { units } \\
\text { Kaliningrad }\end{array}$ & $?$ & $\begin{array}{l}\text { Offense/Defense Two } \\
\text { sided, S-300 - area } \\
\text { defense from opponent } \\
\text { aviation (simulated by BF } \\
\text { aviation) }\end{array}$ & $\begin{array}{l}\text { Officially not } \\
\text { Zapad, synchro- } \\
\text { nized, matching } \\
\text { actions }\end{array}$ \\
\hline Aug 13 & JSC West & $\begin{array}{l}\text { 11th Corp } \\
\text { X? MR units } \\
\text { Kaliningrad }\end{array}$ & $?$ & $\begin{array}{l}\text { Offense. Tank crew } \\
\text { camp, } \\
\text { Live tank shooting, en- } \\
\text { gaging different targets, } \\
\text { reacting to new inputs }\end{array}$ & $\begin{array}{l}\text { Officially not } \\
\text { Zapad, synchro- } \\
\text { nized, matching } \\
\text { actions }\end{array}$ \\
\hline $\begin{array}{l}\text { Aug } \\
14-18\end{array}$ & $\begin{array}{l}\text { JSC } \\
\text { West, }\end{array}$ & $\begin{array}{l}\text { BF Aviation } \\
\text { Kaliningrad }\end{array}$ & $\begin{array}{l}+-500 \mathrm{~S} \\
20 \mathrm{ME}\end{array}$ & $\begin{array}{l}\text { Offense. Tactical aviation } \\
\text { training; Air to air combat, } \\
\text { CAS to land troops }\end{array}$ & $\begin{array}{l}\text { Officially not } \\
\text { Zapad, synchro- } \\
\text { nized, matching } \\
\text { actions }\end{array}$ \\
\hline $\begin{array}{l}\text { Aug } \\
14-18\end{array}$ & JSC West & $\begin{array}{l}\text { 20th OC } \\
\text { 3rd and 144th MD } \\
\text { Voronezh }\end{array}$ & $\begin{array}{l}+-2000 \mathrm{~S} \\
600 \mathrm{ME}\end{array}$ & $\begin{array}{l}\text { Offense/Defense Two- } \\
\text { sided exercise, Alarm, } \\
\text { march, actions in un- } \\
\text { known locations, Logistic } \\
\text { support }\end{array}$ & $\begin{array}{l}\text { Officially not } \\
\text { Zapad, synchro- } \\
\text { nized, matching } \\
\text { actions }\end{array}$ \\
\hline $\begin{array}{l}\text { Aug } \\
15\end{array}$ & $\begin{array}{l}\text { JSC } \\
\text { West, }\end{array}$ & $\begin{array}{l}\text { BF, Signal units } \\
\text { Kaliningrad }\end{array}$ & $500 S$ & $\begin{array}{l}\text { Signal exercise, main- } \\
\text { taining overall C2 (a part } \\
\text { of JSC signal EX) }\end{array}$ & $\begin{array}{l}\text { Officially not } \\
\text { Zapad, synchro- } \\
\text { nized, matching } \\
\text { actions }\end{array}$ \\
\hline $\begin{array}{l}\text { Aug } \\
15\end{array}$ & $\begin{array}{l}\text { JSC } \\
\text { West, }\end{array}$ & $\begin{array}{l}\text { BF } \\
\text { Baltic Sea }\end{array}$ & $\begin{array}{l}+-1000 S \\
20 \mathrm{SS}\end{array}$ & Command training & $\begin{array}{l}\text { Officially not } \\
\text { Zapad, synchro- } \\
\text { nized, matching } \\
\text { actions }\end{array}$ \\
\hline $\begin{array}{l}\text { Aug } \\
15-?\end{array}$ & JSC West & $\begin{array}{l}\text { 1st tank OC (60th } \\
\text { Sig B, 2nd MD, } \\
\text { 4th TD, 228th A } \\
\text { rB, 112 MsB, 53rd } \\
\text { AADB, 20th ABC R } \\
\text { Moscow, Smo- } \\
\text { lensk } \\
\text { Nizhniy Novgorod, } \\
\text { Ivanov }\end{array}$ & $\begin{array}{l}+-5000 S^{*} \\
1000 \mathrm{ME}\end{array}$ & $\begin{array}{l}\text { Offense/Defense. Alarm, } \\
\text { independent marches, } \\
\text { establishing mobile C2, } \\
\text { defense of areas }\end{array}$ & $\begin{array}{l}\text { Officially not } \\
\text { Zapad, synchro- } \\
\text { nized, matching } \\
\text { actions }\end{array}$ \\
\hline $\begin{array}{l}\text { Aug } \\
15-?\end{array}$ & $\begin{array}{l}\text { JSC } \\
\text { Nuclear }\end{array}$ & $\begin{array}{l}\text { Eleven (11) St } \\
\text { MsR } \\
\text { Patrolling } \\
\text { Four regions of } \\
\text { Russia }\end{array}$ & $\begin{array}{l}+-2000 \mathrm{~S} \\
400 \mathrm{ME}\end{array}$ & $\begin{array}{l}\text { Offense/ Defense Stra- } \\
\text { tegic missile patrolling, } \\
\text { imitation of ICBM (Topol) } \\
\text { launch }\end{array}$ & $\begin{array}{l}\text { Officially not } \\
\text { Zapad, synchro- } \\
\text { nized, matching } \\
\text { actions }\end{array}$ \\
\hline Aug 16 & JSC West & $\begin{array}{l}\text { 11th Corp }+\mathrm{NI} \\
\text { 7th MR 336th NIB, } \\
\text { Kaliningrad }\end{array}$ & $\begin{array}{l}+-1500 \mathrm{~S} \\
\text { 150ME }\end{array}$ & $\begin{array}{l}\text { Offense/Defense. Poten- } \\
\text { tially a continuation of the } \\
\text { EX from Aug } 10\end{array}$ & $\begin{array}{l}\text { Officially not } \\
\text { Zapad, synchro- } \\
\text { nized, matching } \\
\text { actions }\end{array}$ \\
\hline
\end{tabular}




\begin{tabular}{|c|c|c|c|c|c|}
\hline Aug 17 & $\begin{array}{l}\text { JSC } \\
\text { West, }\end{array}$ & $\begin{array}{l}\text { 6th OC } \\
\text { 138th MB } \\
\text { Leningrad }\end{array}$ & $\begin{array}{l}+-1000 \mathrm{~S} \\
100 \mathrm{ME}\end{array}$ & $\begin{array}{l}\text { Offense/Defense. } \\
\text { Two sided BTG EX, } \\
\text { communication, artillery } \\
\text { support, UAV, marches, } \\
\text { live firing }\end{array}$ & \\
\hline Aug 17 & $\begin{array}{l}\text { JSC } \\
\text { West }\end{array}$ & $\begin{array}{l}\text { EW unit 16th } \\
\text { EW B } \\
\text { Tambov }\end{array}$ & $\begin{array}{l}+-500 \mathrm{~S} \\
100 \mathrm{ME}\end{array}$ & $\begin{array}{l}\text { Offense/Defense. } \\
\text { Jamming, protection of } \\
\text { own forces from air, }\end{array}$ & $\begin{array}{l}\text { Officially not } \\
\text { Zapad, synchro- } \\
\text { nized, matching } \\
\text { actions }\end{array}$ \\
\hline Aug 17 & JSC West & Aviation Kursk R. & $10 \mathrm{Ai}$ & $\begin{array}{l}\text { Offensive/Defensive } \\
\text { Air to Air, CAS }\end{array}$ & $\begin{array}{l}\text { Officially not } \\
\text { Zapad, synchro- } \\
\text { nized, matching } \\
\text { actions }\end{array}$ \\
\hline Aug 17 & JSC West & $\begin{array}{l}\text { 20th OC } \\
\text { Artillery, RECCE } \\
\text { units } \\
\text { Different locations }\end{array}$ & $?$ & $\begin{array}{l}\text { As part of EX of 20th OC } \\
\text { from Aug 14-18 }\end{array}$ & $\begin{array}{l}\text { Officially not } \\
\text { Zapad, synchro- } \\
\text { nized, matching } \\
\text { actions }\end{array}$ \\
\hline $\begin{array}{l}\text { Aug } \\
18\end{array}$ & $\begin{array}{l}\text { JSC } \\
\text { Nuclear }\end{array}$ & $\begin{array}{l}\text { NF SSBN } \\
\text { "Severodvinsk" } \\
\text { Barents Sea }\end{array}$ & 1 & $\begin{array}{l}\text { SLCM “Kaliber" shooting, } \\
\text { Distance } 600 \mathrm{~km} \text {. }\end{array}$ & $\begin{array}{l}\text { Officially not } \\
\text { Zapad, synchro- } \\
\text { nized, matching } \\
\text { actions }\end{array}$ \\
\hline $\begin{array}{l}\text { Aug } \\
19\end{array}$ & JSC West & $\begin{array}{l}\text { 1st tank OC } \\
\text { Artillery units } \\
\text { Nizhniy Novgorod }\end{array}$ & $\begin{array}{l}+-1000 \mathrm{~S} \\
\text { 300ME }\end{array}$ & $\begin{array}{l}\text { As part of 1st tank OC } \\
\text { EX from Aug } 15 .\end{array}$ & $\begin{array}{l}\text { Officially not } \\
\text { Zapad, synchro- } \\
\text { nized, matching } \\
\text { actions }\end{array}$ \\
\hline Aug 23 & $\begin{array}{l}\text { JSC } \\
\text { Nuclear }\end{array}$ & Strat aviation & $2-6 \mathrm{Ai}$ & $\begin{array}{l}\text { Strategic patrol, Japan, } \\
\text { Yellow and South-China } \\
\text { Seas accompanied by } \\
\text { jets, A } 50 \text { and refueling }\end{array}$ & $\begin{array}{l}\text { Officially not } \\
\text { Zapad, synchro- } \\
\text { nized, matching } \\
\text { actions }\end{array}$ \\
\hline $\begin{array}{l}\text { Aug } \\
23-25\end{array}$ & JSC West & $\begin{array}{l}6^{\text {th }} \text { Air OC } \\
\text { Kursk Astrakhan }\end{array}$ & $\begin{array}{l}+-100 \\
15 \mathrm{Ai}\end{array}$ & $\begin{array}{l}\text { Alarm, Relocation of air- } \\
\text { crafts to reserve airfields }\end{array}$ & $\begin{array}{l}\text { Officially not } \\
\text { Zapad, synchro- } \\
\text { nized, matching } \\
\text { actions }\end{array}$ \\
\hline TOTAL & & & $\begin{array}{l}-+27000 \mathrm{~S} \\
+-4200 \mathrm{ME} \\
-+55 \mathrm{Ai} \\
20 \mathrm{SS}\end{array}$ & & \\
\hline
\end{tabular}

* All numbers come from OS or recalculated/best estimate

Legend: JSC - joint strategic command, OC - operational command, B - brigade, R- regiment,

MD - motorifle division, TD - tank division, NIB - naval infantry brigade, CDB - coastal defense brigade, S - solders/sailors, ME - military equipment (Combat plus other), $\mathrm{SH}$ - surface ships: SS - surface ships; SM - submarines; SA - auxiliary ships A - air frames; Ai - aircrafts. H - Helicopters 


\subsubsection{Zapad-17. "Zapad operation" third stage}

The third stage - a massive (total) state defense involving all state assets and moving to a nuclear war if deterrence fails - started on the $11^{\text {th }}-12^{\text {th }}$ of September. Again, like in the previous stages, a lot of activities were performed by Rapid Reaction and General Purpose units, Nuclear Forces and forces and assets belonging to other state institutions (Russian National Guard, Ministry of Emergencies, Border guards, etc.) were announced as planned and not connected to Zapad. But when a closer look is taken, they obviously fell under one type of activity and were coordinated and synchronized. They all fully matched the content of this stage - massive (total) defense in case of the failure to achieve tasks from previous "Zapad operation" stages. The officially-announced $\mathrm{Za}$ pad-17 days matched the stage, and during those days special demonstrative activities were organized for journalists and military observers from abroad. These demonstrations were oriented to emphasize and demonstrate the Russians' desire to perform total defense with counterattack elements.

Like in previous stages, overall C3 was available again. All participating Rapid Reaction and General Purpose forces established a C3I (C3+Information) and activated mobile command posts ${ }^{122}{ }^{123}$. Command Posts kept working in real time mode and used ABMSs (Andromeda-D, Poliot- $\mathrm{K}^{124}$, etc.). All this allowed HQs located $1,000^{125}$ or even 2,000 ${ }^{126}$ kilometers away from each other to synchronize actions. As a result, again, an overall C3I including everyone from a soldier to the highest HQ was in action ${ }^{127}$.

The start of the stage was a very unusual and interesting one. On the $12^{\text {th }}$ of September a test launch of a ground-based "Jars" intercontinental ballistic missile (ICBM) was done ${ }^{128}$. Unlike short-range ballistic missiles, strategic bombers or submarines which are dual (nuclear and conventional) weapons

\footnotetext{
122 “Связисты Балтийского флота проводят учения в полевых условиях”, Пресс-служба Западного военного округа, 1308 2017, www.mil.ru.

123 “Сеть скрытых командных пунктов создана в рамках учений «Запад-2017»”, видео https:// tvzvezda.ru/news/forces/content/201709201215-4fls.htm.

124 “Подразделения ВДВ оборудовали скрытые полевые пункты управления в рамках ССУ «Запад-2017»”, 1809 2017, www.mil.ru.

125 “Военные связисты России и Белоруссии создали защищенную линию связи длиной около 1000 км для обеспечения учения «Запад-2017»”. 1509 2017, www.mil.ru.

126 “На учении «Запад-2017» связисты ВДВ обеспечивают пункты управления связью на расстоянии до 2 тыс. Км", 1609 2017, www.mil.ru.

127 “Учения «Запад-2017»: проверка «нервной системы» российской армии”, Москва, ТАСС, 19092017.

128 “Россия выполнила испытательный пуск межконтинентальной ракеты «Ярс» с разделяющейся головной частью”, Москва. Интерфакс-АВН , 20092017.
} 
carriers, ICBMs carry only nuclear charges. So, even though it was officially announced as a test launch, in essence, this launch was the start of the third stage - a massive, total and final defense, when a country is ready to use nuclear weapons. Whether this was by accident or not, but this particular launch was highly synchronized with another very strange event, which initiated a lot of subsequent activities. The activities would be considered very appropriate in the event of nuclear attacks. Numerous anonymous phone calls about bombs being planted in different places were made. Those calls in much smaller numbers continue even today at the time of the writing of this text. Russian officials hurried to deny the case being an exercise ${ }^{129}$ or related in any way to Zapad $^{130}$, or identified those calls as being done by provocateurs from abro$\mathrm{ad}^{131}$. Regardless of the cause, those calls allowed other Russian structures and institutions (Russian Guard, Ministry of Emergencies, FSB, etc.) to do what they would have done in the event of mass defense (nuclear war) - a mass evacuation. During the first wave of calls lasting from the $10^{\text {th }}$ to the $12^{\text {th }}$ of September and covering Russia from Kaliningrad ${ }^{132}$ to Omsk, a few dozen civil objects, ranging from administrative buildings to shopping centers, were evacuated with the number of people involved (evacuated) reaching $45,000^{133}$. The exact number of servicemen from the Russian Guard, Ministry of Emergencies and other institutions involved in evacuating, searching, guarding and other activities was not announced, but the count would certainly go into the thousands. Knowing that all those institutions are included in the C3I managed by NDMC and can be (and most probably were) commanded and controlled from it, the third stage became very realistic from the beginning.

Let's reconstruct the scenario for this stage, based on what the forces were doing. The General Purpose forces were preparing for defense. The defense which most probably would be unavoidable given that first two stages failed to force the opponent to negotiate and NATO, beginning wide-scale conventional operations, to push Russian forces out from the occupied territories. In the beginning, in every location defense was prevailing. It started

\footnotetext{
129 “Глава МЧС опроверг версию «учений» в связи с массовой эвакуацией людей в регионах РФ”, Москва. INTERFAX.RU, 20092017.

130 “Глава МЧС: эвакуации в городах России из-за анонимных звонков не связаны с учениями”, https://www.kommersant.ru/doc/3416054.

131 “Генерал ФСБ отметил сезонность анонимных звонков с угрозами взрывов”, Москва, РИА Новости, 12092017.

132 “В Калининграде проверяют анонимные сообщения о минировании зданий”, Калининград, РИА Новости, 12092017.

${ }^{133}$ https://meduza.io/feature/2017/09/12/evakuatsiya-tysyach-lyudey-iz-torgovyh-tsentrov-shkol-vuzovadministratsiy-i-gostinits-po-vsey-rossii-chto-proishodit.
} 
almost at the same time across a front almost $600 \mathrm{~km}$ long, as the Defense Ministry stated ${ }^{134}$. In Kaliningrad the $11^{\text {th }}$ Corps forces started, again claimed-asplanned, an exercise devoted to conduct defense ${ }^{135}{ }^{136}$. They were seconded by aviation and air defense S300, S400 exercises ${ }^{137} 138139$ and a naval special force unit exercise on how to conduct defense against underwater diversions ${ }^{140}$. In the Leningrad region, at the Pechenga training ground around 1,500 motorized infantry soldiers supported by 300 IFVs and APCs kept entrenching and preparing for defense ${ }^{141}$. At the Pumanki training ground next to Murmansk 600 naval infantry solders and around 300 different pieces of equipment and armament, supported by artillery and aviation, kept preparing to repel a naval landing ${ }^{142}$. The $6^{\text {th }}$ tank brigade from the $1^{\text {st }}$ tank OC was boarding trains in the Moscow region to reinforce Russian-Belorussian troops in Belorussia ${ }^{143}$, which were establishing defense in local training grounds ${ }^{144}$. The Northern ${ }^{145}$ and Baltic ${ }^{146}$ fleets left ports, sailed to reserve operational areas ${ }^{147}$ and initiated

\footnotetext{
134 “Путин и Шойгу оценили итоги учений «Запад-2017» на Лужском полигоне”, Полигон Лужский (Ленинградская область), РИА Новости, 18092017.

135 “В Калининградской области проходит учение с подразделениями армейского корпуса Балтийского флота", Отдел информационного обеспечения Балтийского региона (г. Калининград). 1309 2017, www.mil.ru.

136 “Сухопутные подразделения Балтийского флота отрабатывают действия в обороне в рамках учения «Запад-2017»”, 1609 2017, www.mil.ru.

137 “В ходе учения «Запад-2017» военные проверили работу дежурных сил ПВО”, Москва. Интерфакс-АВН, 14092017.

138 “Силы ПВО Балтфлота на учениях «Запад-2017» уничтожили ракеты условного противника” Калининград, ТАСС, 1509 2017, http://tass.ru/armiya-i-opk/4563969.

139 “Подразделения противовоздушной обороны Балтийского флота отразили авиационный удар”, Отдел информационного обеспечения Балтийского региона (г. Калининград), 1509 2017, www.mil.ru. 140 “На Балтийском флоте в рамках ССУ «Запад-2017» бойцы отряда ПДСС задержали условных подводных диверсантов”, 1509 2017, www.mil.ru.

141 “В Заполярье завершилось тактическое учение с подразделениями армейского корпуса Северного флота”, Пресс-служба Северного флота, 1509 2017, www.mil.ru.

142 “Морпехи Северного флота на учениях отразили высадку десанта на Кольский полуостров”, Мурманск, ТАСС, 1809 2017, http://tass.ru/armiya-i-opk/4571107.

143 “Танковая бригада из Подмосковья перебрасывается в Белоруссию на учения”, Москва.

Интерфакс-АВН, 14092017.

144 “Подразделения 3ВО заняли оборонительные рубежи на белорусском военном полигоне Осиповичский в рамках ССУ «Запад-2017»”, 1609 2017, www.mil.ru.

145 “В Баренцевом море начались учения Северного флота”, пресс-служба Северного флота, РИА Новости , 14092017.

146 “Корабли Балтийского флота вышли в море на учениях «Запад-2017”, пресс-служба Западного военного округа, 1609 2017, http://kgd.ru/news/society/item/66883-korabli-baltijskogo-flota-vyshli-vmore-na-ucheniyah-zapad-2017.

147 “Силы Беломорской военно-морской базы Северного флота развёрнуты в Баренцевом море”, Пресс-служба Северного флота, 1609 2017, www.mil.ru.
} 
air defense and defense against surface ships training 148149150 . The same was done by the $6^{\text {th }}$ air OC from JSC "West" which carried out a speedy relocation of all air frames from the main airfields to reserve ones ${ }^{151}$. Special units were preparing for defense actions also. JSC "West” NBC units in Luga were exercising how to conceal movements of their own troops by aerosol smoke ${ }^{152}$, EW specialists exercised protection of their own troops against opponent air reconnaissance ${ }^{153}$ and withstanding enemies' cyber-attacks against their own C3 $3^{154}$.

To engage advancing troops at long distances and before first contact with defenders, new tactical elements (like helicopter ambushes) ${ }^{155}$ were exercised and LRPGMs were applied. The last was done by missile brigades which struck opponent command and communication posts by "Iskander" and "Tochka-U” rockets ${ }^{156} 157$. The same, just as a part of real combat operation, was done in the Mediterranean Sea where Russian submarines "Velikiy Novgorod" and "Kalino" launched "Caliber" attacks against real targets in Syria" ${ }^{158}$. Rapid Reaction Forces were involved in delay and restrain operations by performing combat raids behind the enemy ${ }^{159}$ or parachuting and executing diversions behind enemy lines, selecting targets for PRPGM strikes and doing everything to

\footnotetext{
148 “Корабельная ударная группа и истребительная авиация СФ отразили воздушные атаки условного противника в Баренцевом море”, Пресс-служба Северного флота, 1509 2017, www.mil.ru.

149 “Корвет Балтфлота в ходе учения «Запад-2017» поразил крылатой ракетой корабль условного противника”, Балтийск. пресс-службе Балтфлота РФ, Интерфакс, 19092017.

150 “Корабли Балтфлота выполнили артиллерийские стрельбы на учениях «Запад-2017»”, отдела информационного обеспечения пресс-службы ЗВО по Балтийскому флоту, 1709 2017, Балтийск (Калининградская область), РИА Новости, 17092017.

151 “Авиация 3ВО передислоцируется на оперативные аэродромы в рамках проведения ССУ «Запад-2017»”, 1509 2017, www.mil.ru.

152 “Специалисты РХБ защиты ЗВО скрыли передислокацию войск на учении «Запад-2017»”, 1509 2017, www.mil.ru.

153 “Военные специалисты РЭБ ЗВО на учении «Запад-2017» прикрыли развертывание войск союзников от беспилотников «противника»”, 1509 2017, www.mil.ru.

154 “Военные связисты ЗВО отразили кибератаки «противника» на учении «Запад-2017»”,

1509 2017, www.mil.ru.

155 “Вертолеты $3 В О$ продемонстрировали тактику уничтожения высокомобильного «противника» из засад в ходе учения «Запад-2017»”, 1709 2017, www.mil.ru.

156 “Ракетчики 3ВО в ходе ССУ «Запад-2017» уничтожили военную технику и командный пункт условного противника на полигоне в Ленинградской области”, 1709 2017, www.mil.ru.

${ }^{157}$ RTR News, “Vesti”, 16092017.

158 “Подлодки «Великий Новгород» и «Колпино» нанесли удар «Калибрами» по объектам ИГ в Сирии”, Москва, ТАСС, 1409 2017, http://tass.ru/armiya-i-opk/4561914.

159 “В ходе учения «Запад-2017» поднят по тревоге ряд подразделений ВДВ России”, Москва. Интерфакс-АВН, 14092017.
} 
restrain the advance of enemy troops ${ }^{160}$. To recover and restore battle damage, logistic units exercised damaged vehicles evacuation from a battlefield; field repair ${ }^{161}$ and troop resupply activities ${ }^{162}$.

With the enemy stopped and tied-up in defensive battles ${ }^{163}{ }^{164}$, preparation for a counter-strike began ${ }^{165}$. As soon as the situation allowed, an offense started on all fronts extending from Leningrad ${ }^{166}$ to Kaliningrad ${ }^{167}$ and Belorussia. A lot of attention went towards providing this counter-offense with credible air support ${ }^{168}{ }^{169}$. The second part of the official Zapad-17 exercise witnessed active counter-offensive activities ${ }^{170}$. In Russia, at the same time, a second wave of bombing calls happened. The calls remained declared as having nothing in common with the exercise, but as a result of this, the Russian Guard and other forces continued searching and safeguarding objects located mostly in Russian western and southern regions and performing real evacuation of people who happened to be in those objects. The numbers became impressive, more than 200,000 people were evacuated and more than 700 objects searched $^{171}$. This suggests the assumption that Russia was simulating a situation then the West, while repelling successful Russian counter attacks, responded by multiple strikes deep into Russian territory.

\footnotetext{
160 “Ульяновское соединение ВДВ проведет первое тактическое учение с применением боевых машин БМД-4М и БТР-МДМ «Ракушка»”, Департамент информации и массовых коммуникаций Министерства обороны Российской Федерации, 1309 2017, www.mil.ru.

161 “Специалисты МТО проведут в ходе ССУ «Запад-2017» тренировки по обслуживанию и экстренному ремонту ВВТ”,16 09 2017, www.mil.ru.

162 “Бригада материально-технического обеспечения 3ВО в ходе учения «Запад-2017» развернула ремонтные мастерские”, 1609 2017, www.mil.ru.

163 “Мотострелки общевойсковой армии ЗВО уничтожили десант НВФ в ходе основного этапа учения «Запад-2017»”,17 09 2017, www.mil.ru.

164 “Лётчики Балтфлота уничтожили подлодку условного противника на учениях «Запад-2017”, Минобороны РФ, 1609 2017, http://kgd.ru/news/society/item/66895-ljotchiki-baltflota-unichtozhilipodlodku-uslovnogo-protivnika-na-ucheniyah-zapad-2017.

165 “Подразделения ВДВ готовятся к погрузке в самолеты ВТА для последующего применения в качестве парашютного тактического десанта”, 1709 2017, www.mil.ru.

166 “Су-25 на учениях «Запад-2017» уничтожили колонну «противника», департамент информации и массовых коммуникаций Минобороны России”, С.-Петербург, РИА Новости, 18092017.

167 “Су-24 выполнили практическое бомбометание на учениях «Запад-2017», пресс-служба Западного военного округа (ЗВО) по Балтийскому флоту”, Калининград, РИА Новости, 17092017. 168 “Российские Су-24М на учениях «Запад-2017» уничтожили объекты «противника», С.ПЕТЕРБУРГ, РИА Новости, 18092017.

169 Экипажи ударных вертолетов ЗВО выполнили прикрытие наземной группировки войск с воздуха в рамках учения «Запад-2017», 1709 2017, www.mil.ru.

170 “Мотострелки Балтийского флота под Калининградом ликвидировали условных террористов в ходе маневров «Запад-2017»”, Полигон «Правдинский» (Калининградская область), ИнтерфаксАBН, 18092017.

${ }^{171}$ А. Гальперин “Более 200 тысяч человек эвакуировали в РФ за неделю из-за звонков анонимов”, Москва, РИА Новости, 19092017.
} 
Russia responded with limited nuclear strikes. These were imitated by launching a "Iskander" missile, which can carry a nuclear charge, to maximum distance in the Kapustin Jar ${ }^{172}$ firing range; launching a mobile ICBM "Jars" in Plesetsk ${ }^{173}$ and strategic bombers Tu22M3 which flew an announced-as-planned event again, next to the Baltic States and Norway ${ }^{174}$. After a few days, the MOD announced the beginning of massive, planned checks of combat readiness in all JSCs. Now not dozens but hundreds of units left their permanent locations, moving to training grounds and engaging in different activities. Bombing calls kept coming. The National Guard and other forces, with NDMC supervising everything, continued to work. In total, since the first calls were made until the middle of October, more than 2,460 objects were search in 170 Russian cities ${ }^{175}$ and 1 percent of the entire population or 1.4 million people evacuated ${ }^{176}$. This was exactly the situation which would occur if nukes were used.

On the $26^{\text {th }}$ of October, the worst-case scenario of the third stage - a mass exchange of nuclear strikes - was played out in the NDMC. According to Russian legislature, only the President can authorize usage of nuclear weapons. On the $26^{\text {th }}$ of October a Russian National Security Board meeting took place ${ }^{177}$. It is quite probable that right after it, the entire Board moved to the NDMC premises and, now as its Supreme Commander (Nuclear) Cell, exercised a decision to use nukes. The same night, the Russian nuclear triad imitated a massive nuclear strike by simultaneously launching an ICMB in Plesetsk, ICBMs from three submarines in the Barents and Okhotsk seas and cruise missiles from strategic bombers. It was declared that all missiles hit targets located thousands of kilometers away ${ }^{178}{ }^{179}$. Also, it was announced that Putin,

\footnotetext{
172 “Комплекс «Искандер-М» на учениях запустил ракету на максимальную дальность”, Москва, РИА Новости 18092017.

173 “Испытательный пуск: ракета «Ярс» поразила цель на Камчатке”, 2009 2017, https://tvzvezda.ru/ news/forces/content/201709201139-d0to.htm.

174 “Бомбардировщики Ту-22М3 совершили плановые полеты над нейтральными водами Балтийского и Норвежского морей”, 2109 2017, https://tvzvezda.ru/news/forces/ content/201709210004-urtl.htm.

175 “В России эвакуировали уже более миллиона человек в связи с «минированиями», Москва, РИА Новости, 10102017.

${ }^{176}$ А. Карапетян, "В РФ почти 1,4 миллиона человек эвакуировали с начала волны «минирований»”, Москва, РИА Новости 2610201.

${ }^{177}$ RTR news "Vesti, 19:00”, 26102017.

178 “Минобороны провело тренировку по управлению Стратегическими ядерными силами”, Москва, РИА Новости, 26102017.

179 “В рамках учений РВСН с Плесецка запущена МБР «Тополь» - Минобороны РФ”, Москва, Интерфакс-АВН, 26102017.
} 
as the supreme commander, personally authorized the launches ${ }^{180}$. This was the end of the "Zapad operation" test and Zapad exercise. The next day, in the MOD board meeting the defense minister S. Shoigu announced that the objectives of the Zapad exercise were achieved ${ }^{181}$. Russia not only checked all its procedures until the end, but, at the same time, sent a message to the West stating that it was ready "to cross the Rubicon" and to use massive nuclear strikes. Time will tell whether this will become an annual Russian response to the USA nuclear triad exercise "Global Thunder"182.

Summarizing everything that happened during this stage, we see that the prevailing offense, presented in the earlier stages, was substituted by widescale defense mostly done by conventional forces and counter-offense as soon as the advancing forces had been stopped. The defense was supported less from the air and PLRGMs, but seldom were nuclear strikes exercised, and forces did show they were prepared to handle the enemy's nuclear response. A great variety of other state forces, agencies or institutions were involved in real activities for different reasons. The amount of forces participating in the third stage was difficult to estimate. Nevertheless, counting only the figures from the MOD, there were more than 27,000 soldiers, around 2,000 combat and other equipment, 130 air frames and 50 ships were involved in all the above-mentioned activities (see Table 3). We can only guess how many troops and equipment from other institutions were involved. The question of whether we should count the evacuated civilians as participants of the exercise remains open to discussion.

Table 3. Zapad, 2017 September, likely the $3^{\text {rd }}$ "Massive Defense" stage

\begin{tabular}{|l|l|l|l|l|l|}
\hline Date & JSC & Unit/ Location & Size & Action & Remarks \\
\hline $\begin{array}{l}\text { SEP } \\
12\end{array}$ & JSC Nuclear & $\begin{array}{l}\text { Strategic missiles } \\
\text { OC }\end{array}$ & $\begin{array}{l}? \\
1 \text { ballistic } \\
\text { missile }\end{array}$ & Defense/Offense & $\begin{array}{l}\text { Officially not Zapad, } \\
\text { synchronized, } \\
\text { matching actions }\end{array}$ \\
\hline $\begin{array}{l}\text { SEP } \\
13-?\end{array}$ & JSC West & $\begin{array}{l}\text { Signal troops in } \\
\text { Kaliningrad }\end{array}$ & $\begin{array}{l}+-400 S \\
+-30 \mathrm{ME}\end{array}$ & $\begin{array}{l}\text { Establish and main- } \\
\text { taining overall C2 }\end{array}$ & $\begin{array}{l}\text { Officially not Zapad, } \\
\text { synchronized, } \\
\text { matching actions }\end{array}$ \\
\hline $\begin{array}{l}\text { SEP } \\
13\end{array}$ & JSC West & $\begin{array}{l}11^{\text {th }} \mathrm{Co}, 79^{\text {th }} \mathrm{MBr} \text { or } \\
7^{\text {th }} \mathrm{MR}\end{array}$ & $\begin{array}{l}+-1000 \mathrm{~S} / \\
+-100 \mathrm{ME} \\
+-4 \mathrm{Ai} \\
\text { and } \mathrm{H}\end{array}$ & $\begin{array}{l}\text { Defense and counter } \\
\text { attack }\end{array}$ & $\begin{array}{l}\text { Officially not Zapad, } \\
\text { synchronized, } \\
\text { matching actions }\end{array}$ \\
\hline
\end{tabular}

\footnotetext{
180 “Путин на учениях в четверг запустил четыре баллистические ракеты”, Москва, РИА Новости, 26102017.

${ }^{181}$ А. Тихонов, “Факторы роста обороноспособности”, Красная звезда, 29102017

http://www.redstar.ru/index.php/newspaper/item/34943-faktory-rosta-oboronosposobnosti.

${ }^{182}$ This year the annual US nuclear triad exercise Global Thunder 2018 started on the $30^{\text {th }}$ of October.
} 


\begin{tabular}{|c|c|c|c|c|c|}
\hline $\begin{array}{l}\text { SEP } \\
13\end{array}$ & JSC West & SOF units Tambov & $?$ & $\begin{array}{l}\text { Defense/Offense } \\
\text { Landing in the rear, } \\
\text { reconnaissance }\end{array}$ & $\begin{array}{l}\text { Officially not Zapad, } \\
\text { obvious synchroni- } \\
\text { zation and matching } \\
\text { actions }\end{array}$ \\
\hline $\begin{array}{l}\text { SEP } \\
14\end{array}$ & JSC West & $\begin{array}{l}11^{\text {th }} \text { Co } \\
\text { Air defense }\end{array}$ & $\begin{array}{l}+-100 \mathrm{~S} \\
+-10 \mathrm{Ai}\end{array}$ & $\begin{array}{l}\text { Defense } \\
\text { Air defense }\end{array}$ & Officially Zapad \\
\hline $\begin{array}{l}\text { SEP } \\
14\end{array}$ & $\begin{array}{l}\text { JSC West } \\
\text { JSC Nuclear }\end{array}$ & $\begin{array}{l}6^{\text {th }} \text { Air OC } \\
\text { Strat aviation OC }\end{array}$ & $\begin{array}{l}+-? 00 \mathrm{~S} \\
+-20 \mathrm{Ai}\end{array}$ & $\begin{array}{l}\text { Defense/Offense } \\
\text { Air counterattack }\end{array}$ & Officially Zapad \\
\hline $\begin{array}{l}\text { SEP } \\
14\end{array}$ & $\begin{array}{l}\text { JSC } \\
\text { Air space } \\
\text { forces }\end{array}$ & $\begin{array}{l}\text { Air defense } \\
\text { Baltic fleet }\end{array}$ & $\begin{array}{l}+-500 \mathrm{~S} \\
+-50 \mathrm{ME} \\
7 \mathrm{SS}\end{array}$ & $\begin{array}{l}\text { Air defense } \\
\text { Aircraft, } \$ 300, \$ 400 \text {, }\end{array}$ & Officially Zapad \\
\hline $\begin{array}{l}\text { SEP } \\
14- \\
20\end{array}$ & JSC West & $\begin{array}{l}1^{\text {st }} \text { Tank OC, } 4^{\mathrm{TH}} \mathrm{tdV} \\
6^{\text {th }} \mathrm{TBr} \text { Belarus }\end{array}$ & $\begin{array}{l}+-3000 \mathrm{~S} \\
+-300 \mathrm{ME}\end{array}$ & $\begin{array}{l}\text { Defense, Offense Re- } \\
\text { inforcement (Russian } \\
\text { part), counterattack }\end{array}$ & Officially Zapad \\
\hline $\begin{array}{l}\text { SEP } \\
14- \\
20\end{array}$ & JSC West & $\begin{array}{l}\text { Russian- Belarusian } \\
\text { unified military group } \\
\text { Belarus }\end{array}$ & $\begin{array}{l}-+ \\
0000 \mathrm{~S} \\
+-300 \mathrm{ME} \\
+-50 \mathrm{Ai} \\
\mathrm{H}\end{array}$ & $\begin{array}{l}\text { Defense/ Offense } \\
\text { Defense and counter- } \\
\text { attack }\end{array}$ & Officially Zapad \\
\hline $\begin{array}{l}\text { SEP } \\
14- \\
18\end{array}$ & JSC North & Northern fleet & $\begin{array}{l}+-5000 \mathrm{~S} \\
+-300 \mathrm{ME} \\
+-30 \mathrm{~A} \\
+-20 \mathrm{SS} \\
10 \mathrm{SM} / 30 \\
\mathrm{SA}\end{array}$ & $\begin{array}{l}\text { Defense. Ships leav- } \\
\text { ing bases. }\end{array}$ & $\begin{array}{l}\text { Officially not Zapad, } \\
\text { obvious synchroni- } \\
\text { zation and match of } \\
\text { actions }\end{array}$ \\
\hline $\begin{array}{l}\text { SEP } \\
14\end{array}$ & $\begin{array}{l}\text { JSC Rapid } \\
\text { reaction }\end{array}$ & $\begin{array}{l}76^{\text {th }}, 106^{\text {th }} 98^{\text {th }} \text { Air- } \\
\text { borne Div }\end{array}$ & $?$ & $\begin{array}{l}\text { Defense, Offense } \\
\text { Counterattack/Rein- } \\
\text { forcement }\end{array}$ & Officially Zapad \\
\hline $\begin{array}{l}\text { SEP } \\
14\end{array}$ & JSC South & $\begin{array}{l}\text { Black Sea fleet } \\
\text { Syria }\end{array}$ & $\begin{array}{l}+-100 S \\
2 \mathrm{SM}\end{array}$ & $\begin{array}{l}\text { Defense } \\
\text { Launching CRM }\end{array}$ & $\begin{array}{l}\text { Officially not Zapad, } \\
\text { obvious synchroni- } \\
\text { zation }\end{array}$ \\
\hline $\begin{array}{l}\text { SEP } \\
15\end{array}$ & JSC West & $\begin{array}{l}\text { OC Baltic fleet } \\
\text { Naval SOF }\end{array}$ & $\begin{array}{l}+-50 S \\
+-2 S A\end{array}$ & $\begin{array}{l}\text { Defense } \\
\text { Undersea diversion } \\
\text { prevention }\end{array}$ & Officially Zapad \\
\hline $\begin{array}{l}\text { SEP } \\
15\end{array}$ & JSC West & $\begin{array}{l}11^{\text {th }} \mathrm{Co}, 79^{\text {th }} \mathrm{MBr} \text { or } \\
7^{\text {th }} \mathrm{MR}\end{array}$ & $\begin{array}{l}+-000 \mathrm{~S} \\
? ? \mathrm{ME}\end{array}$ & $\begin{array}{l}\text { Defense } \\
\text { Ambushes / counter- } \\
\text { attacks }\end{array}$ & Officially Zapad \\
\hline $\begin{array}{l}\text { SEP } \\
15\end{array}$ & JSC West & $\begin{array}{l}6^{\text {th }} \text { Air OC, } \\
\text { OC Baltic Fleet } \\
\text { Aviation } \\
\text { Air defense, Fleet } \\
\text { Aviation }\end{array}$ & $\begin{array}{l}+-200 \mathrm{~S} \\
20 \mathrm{Ai}\end{array}$ & Air defense & Officially Zapad \\
\hline $\begin{array}{l}\text { SEP } \\
15\end{array}$ & JSC West & $\begin{array}{l}\text { ABC units } \\
\text { Luga }\end{array}$ & $\begin{array}{l}+-100 S \\
\text { xME }\end{array}$ & $\begin{array}{l}\text { Defense } \\
\text { Camouflage }\end{array}$ & Officially Zapad \\
\hline
\end{tabular}




\begin{tabular}{|c|c|c|c|c|c|}
\hline $\begin{array}{l}\text { SEP } \\
15\end{array}$ & JSC West & $\begin{array}{l}\text { EW units } \\
\text { Luga }\end{array}$ & $?$ & $\begin{array}{l}\text { Defense } \\
\text { EW Protection of } \\
\text { Assets }\end{array}$ & Officially Zapad \\
\hline $\begin{array}{l}\text { SEP } \\
15\end{array}$ & JSC West & Signal Units & $?$ & $\begin{array}{l}\text { Defense } \\
\text { Cyber defense of } \\
\text { Communication }\end{array}$ & Officially Zapad \\
\hline $\begin{array}{l}\text { SEP } \\
16\end{array}$ & $\begin{array}{l}\text { JSC West } \\
\text { Luga }\end{array}$ & $\begin{array}{l}6^{\text {th }} \mathrm{OC} \\
25^{\text {th }} \mathrm{MBr}, 138^{\text {th }} \mathrm{Mbr} \\
2^{\text {nd }} \mathrm{MDv} 448^{\text {th }}, 26^{\text {th }} \\
\mathrm{MsBr}\end{array}$ & $\begin{array}{l}+-1500 \mathrm{~S} \\
+-300 \mathrm{ME} \\
+-30 \mathrm{~A}\end{array}$ & $\begin{array}{l}\text { Defense Counterat- } \\
\text { tack } \\
\text { Iskander and Tochka } \\
\text { U launching }\end{array}$ & Officially Zapad \\
\hline $\begin{array}{l}\text { SEP } \\
15\end{array}$ & $\begin{array}{l}\text { JSC West } \\
\text { Luga }\end{array}$ & JSC Logistic Br & $\begin{array}{l}? 00 \mathrm{~S} \\
+-100 \mathrm{ME}\end{array}$ & $\begin{array}{l}\text { Defense } \\
\text { Recovery of battle } \\
\text { damage, field logistics }\end{array}$ & Officially Zapad \\
\hline $\begin{array}{l}\text { SEP } \\
14- \\
18\end{array}$ & JSC North & Northern fleet & $\begin{array}{l}+-5000 \mathrm{~S} \\
+-300 \mathrm{ME} \\
+-30 \mathrm{~A} \\
+-/ 20 \mathrm{SS} \\
10 \mathrm{SM} / 30 \\
\mathrm{SA}\end{array}$ & $\begin{array}{l}\text { Defense } \\
\text { against sea and air } \\
\text { assault in the sea, } \\
\text { artillery and cruise } \\
\text { missiles shooting }\end{array}$ & $\begin{array}{l}\text { Officially not Zapad, } \\
\text { obvious synchroni- } \\
\text { zation and matching } \\
\text { actions }\end{array}$ \\
\hline $\begin{array}{l}\text { SEP } \\
15\end{array}$ & $\begin{array}{l}\text { JSC North } \\
\text { Pechenga }\end{array}$ & Land forces & $\begin{array}{l}+-1500 \mathrm{~S} \\
+-300 \mathrm{ME}\end{array}$ & $\begin{array}{l}\text { Defense } \\
\text { Against naval landing }\end{array}$ & $\begin{array}{l}\text { Officially not Zapad, } \\
\text { obvious synchroni- } \\
\text { zation and matching } \\
\text { actions }\end{array}$ \\
\hline $\begin{array}{l}\text { SEP } \\
15\end{array}$ & JSC Nuclear & OC strat aviation & $\begin{array}{l}? \\
1 \mathrm{Ai}\end{array}$ & $\begin{array}{l}\text { Defense/offense } \\
\text { Strat aviation patrol } \\
\text { Accident }\end{array}$ & $\begin{array}{l}\text { Officially not Zapad, } \\
\text { obvious synchroni- } \\
\text { zation and match- } \\
\text { ing actions }\end{array}$ \\
\hline $\begin{array}{l}\text { SEP } \\
15- \\
17\end{array}$ & JSC West & $\begin{array}{l}\text { OC Baltic Fleet } \\
\text { 25th CDB } \\
\text { Kaliningrad }\end{array}$ & $\begin{array}{l}? 000 S \\
20 \mathrm{SS}\end{array}$ & $\begin{array}{l}\text { Defense } \\
\text { against sea and air } \\
\text { assault in the sea, ar- } \\
\text { tillery shooting, "Bal", } \\
\text { Bastion" systems }\end{array}$ & Officially Zapad \\
\hline $\begin{array}{l}\text { SEP } \\
15\end{array}$ & $\begin{array}{l}\text { JSC Rapid } \\
\text { reaction }\end{array}$ & $108^{\text {th }}$ Air-borne Dv & $\begin{array}{l}+-500 \mathrm{~S} \\
+-10 \mathrm{ME}\end{array}$ & $\begin{array}{l}\text { Offense } \\
\text { Raids in opponent's } \\
\text { rear }\end{array}$ & Officially Zapad \\
\hline $\begin{array}{l}\text { SEP } \\
15 \\
-18\end{array}$ & $\begin{array}{l}\text { JSC } \\
\text { West } \\
\text { Luga }\end{array}$ & $\begin{array}{l}1^{\text {st }} \text { Tank OC, } 2^{\text {nd }} \\
M D v, 138 \text { th and } 25 \\
M B r, \text { other units }\end{array}$ & $\begin{array}{l}+-1500 \mathrm{~S} \\
+-300 \mathrm{ME} \\
+-10 \mathrm{~A} \\
\text { and } \mathrm{H}\end{array}$ & $\begin{array}{l}\text { Defense } \\
\text { Artillery engaging } \\
\text { opponent's assault. } \\
\text { Counter attack }\end{array}$ & Officially Zapad \\
\hline $\begin{array}{l}\text { SEP } \\
16\end{array}$ & JSC West & $\begin{array}{l}6^{\text {th }} \text { Air OC } \\
\text { Leningrad } \\
\text { Kaliningrad }\end{array}$ & $\begin{array}{l}+-100 \mathrm{~S} \\
+-10 \mathrm{~A}\end{array}$ & $\begin{array}{l}\text { Defense/Offense } \\
\text { Two sided } \\
\text { CAS and AAD activi- } \\
\text { ties }\end{array}$ & Officially Zapad \\
\hline $\begin{array}{l}\text { SEP } \\
16\end{array}$ & $\begin{array}{l}\text { JSC West } \\
\text { Belarus }\end{array}$ & $\begin{array}{l}\text { Logistic units from } \\
\text { JSC West }\end{array}$ & $?$ & $\begin{array}{l}\text { Defense } \\
\text { Recovery of battle } \\
\text { damage, field logistics }\end{array}$ & Officially Zapad \\
\hline $\begin{array}{l}\text { SEP } \\
16- \\
18\end{array}$ & $\begin{array}{l}\text { JSC West } \\
\text { Luga }\end{array}$ & Army aviation units & $\begin{array}{l}\text { X?S? } \\
+-10 \mathrm{H}\end{array}$ & $\begin{array}{l}\text { Defense/Offense } \\
\text { Helicopter ambush, } \\
\text { CAS }\end{array}$ & Officially Zapad \\
\hline
\end{tabular}




\begin{tabular}{|c|c|c|c|c|c|}
\hline $\begin{array}{l}\text { SEP } \\
17- \\
20\end{array}$ & $\begin{array}{l}\text { JSC West } \\
\text { Belarus }\end{array}$ & $\begin{array}{l}1^{\text {st }} \text { Tank Army, } \\
4^{\text {th }} \text { TDv and } 6^{\text {th }} \mathrm{T} \mathrm{Br} .\end{array}$ & $\begin{array}{l}+-3500 \mathrm{~S} \\
+-500 \mathrm{ME} \\
\geq 10 \mathrm{~A} \\
\text { and } \mathrm{H}\end{array}$ & $\begin{array}{l}\text { Defense } \\
\text { Defense and counter- } \\
\text { attack after }\end{array}$ & Officially Zapad \\
\hline $\begin{array}{l}\text { SEP } \\
17- \\
20\end{array}$ & $\begin{array}{l}\text { JSC West } \\
\text { Luga }\end{array}$ & $\begin{array}{l}\text { JSC West Logistic } \\
\text { troops }\end{array}$ & $\begin{array}{l}+-? 00 \mathrm{~S} \\
+-30 \mathrm{ME}\end{array}$ & $\begin{array}{l}\text { Defense } \\
\text { Logistic and } \\
\text { maintenance/ water } \\
\text { purification }\end{array}$ & Officially Zapad \\
\hline $\begin{array}{l}\text { SEP } \\
18\end{array}$ & JSC RRF & $\begin{array}{l}\text { Naval infantry Br. } \\
\text { Pumanki, Murmansk }\end{array}$ & $\begin{array}{l}+-600 S \\
? \mathrm{ME}\end{array}$ & $\begin{array}{l}\text { Defense } \\
\text { Coastal defense }\end{array}$ & Officially Zapad \\
\hline $\begin{array}{l}\text { SEP } \\
19\end{array}$ & $\begin{array}{l}\text { JSC Rapid } \\
\text { reaction }\end{array}$ & $76^{\text {th }}$ air-borne Dv & $\begin{array}{l}+-500 \mathrm{~S} \\
+-10 \mathrm{ME} \\
6 \mathrm{~A}\end{array}$ & $\begin{array}{l}\text { Defense/Offense } \\
\text { counter attack, cap- } \\
\text { ture of airfield }\end{array}$ & Officially Zapad \\
\hline $\begin{array}{l}\text { SEP } \\
20\end{array}$ & JSC West & OC Baltic fleet & $\begin{array}{l}+-1000 S \\
+-\geq 20 \text { SS } \\
x H\end{array}$ & $\begin{array}{l}\text { Defense/Offense de- } \\
\text { fense against sea and } \\
\text { air assault/ support } \\
\text { naval landing }\end{array}$ & Officially Zapad \\
\hline $\begin{array}{l}\text { SEP } \\
14- \\
20\end{array}$ & & Topography troops & $\begin{array}{l}+-250 \mathrm{~S} \\
+-30 \mathrm{ME}\end{array}$ & $\begin{array}{l}\text { Defense/Offense } \\
\text { Improvement of } \\
\text { positioning, navigating } \\
\text { and aiming }\end{array}$ & Officially Zapad \\
\hline $\begin{array}{l}\text { SEP } \\
20\end{array}$ & JSC Nuclear & $\begin{array}{l}\text { Strategic missiles } \\
\text { OC }\end{array}$ & $\begin{array}{l}? \\
1 \text { ballistic } \\
\text { missile }\end{array}$ & $\begin{array}{l}\text { Defense/Offense } \\
\text { Ballistic missile test }\end{array}$ & $\begin{array}{l}\text { Officially not Zapad, } \\
\text { obvious synchroni- } \\
\text { zation and matching } \\
\text { actions }\end{array}$ \\
\hline $\begin{array}{l}\text { OCT } \\
26\end{array}$ & JSC Nuclear & $\begin{array}{l}\text { Strategic missiles } \\
\text { OC } \\
\text { Strategic Aviation } \\
\text { OC } \\
\text { Submarine forces } \\
\text { OC }\end{array}$ & $\begin{array}{l}4 \text { ballistic } \\
\text { and } X ? \\
\text { Cruise } \\
\text { missiles }\end{array}$ & $\begin{array}{l}\text { Defense, Massive } \\
\text { NUCLEAR STRIKE }\end{array}$ & $\begin{array}{l}\text { Officially not Zapad, } \\
\text { obvious synchroni- } \\
\text { zation and matching } \\
\text { actions }\end{array}$ \\
\hline $\begin{array}{l}\text { SEP } \\
10 \\
\text { OCT } \\
26\end{array}$ & $\begin{array}{l}\text { Russian Na- } \\
\text { tional Guard } \\
\text { other forces }\end{array}$ & $?$ & $? 0000$ & $\begin{array}{l}\text { Defense. Massive } \\
\text { evacuation }\end{array}$ & $\begin{array}{l}\text { Officially denied as } \\
\text { being an exercise }\end{array}$ \\
\hline $\begin{array}{l}\text { TO- } \\
\text { TAL }\end{array}$ & & & $\begin{array}{l}-+27000 \mathrm{~S} \\
+-2000 \mathrm{ME} \\
-+130 \mathrm{Ai} \\
50 \mathrm{SS}\end{array}$ & & \\
\hline
\end{tabular}

* All numbers come from OS or recalculated/best estimate

Legend: JSC - joint strategic command, OC - operational command, B - brigade, R- regiment,

$\mathrm{MD}$ - moto-rifle division, TD - tank division, NIB - naval infantry brigade, CDB - coastal defense brigade, S - soldiers/sailors, ME - military equipment (Combat plus other), SH - surface ships: SS - surface ships; SM - submarines; SA - auxiliary ships; A - air frames; Ai - aircrafts; $\mathrm{H}$ - helicopters 


\section{Conclusions}

Russia tends to abide by the principle to have military activities planned in detail. This means that for every military activity, including a war with an opponent in the West, it has detailed plans, which are checked and updated from time to time. Quite probably, while preparing its plans on how to fight in the West, some assumptions were made. At first, the use of armed forces would bear results only if troops act quickly, effectively and are able to secure achievements. And second, large numbers of casualties and loses suffered by the enemy or the expectation of these loses while fighting diminishes its will to continue fighting and motivates one to start negotiations. In Kosovo, the Zapad-99 and Zapad-09 exercises most probably assured Russia that the West was not able to respond decisively, so there would be time to prepare for new actions (or total defense). The cases of Georgia 2008 and Crimea 2014 also reassured Russia that, if negotiations did start, the gains achieved by military means could most probably be safeguarded.

Russia considers that the principles of detailed planning could be successfully used in recent wars. There were two in weak points of detailed planning, which became obvious in the past. At first, there was an enormous number of situations that could appear in a campaign and which required too much work to be done by officers. As a result, a lot of potential situations were left without due attention. Second, it took a long time to collect, receive and analyze information and to pass new directives on to troops. As a result, the reaction to any change was slow and/or any unforeseen changes usually led to the collapse of the operation. The Russian military assumes that recent technologies allow solving both problems. Computers and huge NDMC computing capabilities allow designing as many situations as one might need and to redesign them quickly if required. Technological progress in surveillance, communication and other fields allows establishing an overall C3 and C3I and employing modern ABMS. This makes it possible to not only update/correct/ change plans quickly, but to pass directives immediately on to units in the field as well. In this case, having detailed plans and pre-planned potential changes available allows the country's forces to act faster, more effectively and achieving the desired results without hesitation. Troops on the battle field have to concentrate only on how to quickly implement the pre-planned steps or the received directives and are free to improvise at the tactical level. Then the opponent is forced to waste time while continuously re-planning and coordinating plans with other HQs to respond to the quick moves of your troops. 
Based on the analysis of all the Zapad exercises starting from 1999, one might state that a war with an opponent in the West or "Zapad operation" consists of three stages. To achieve success, the first two stages would be enough, but in a case of failure, all three would be required. Since 1999, Russia kept checking its plan, at first mostly theoretically, and only separate stages were exercised and later, since 2013 (after the end of the first stage of military reform and the appointment of S. Shoigu as the minister), practically and on a wider scale. Exercises following Zapad-13, such as Vostok-14, Centr-15 and Caucasus-16 were used to check separate elements from different stages. Zapad-17 checked them incorporated into one entire action.

Even though the Russian political military leadership stated it was satisfied with the Zapad-17 exercise, based on the information available, some planned actions failed and the set objectives were not achieved. Success was obvious in establishing an overall C3, but a lot still has to be done to transform it into a fully fledged C3I. Evident progress was made in EW, logistics and maintenance, rearmament and PLRGMs, navigation and testing of new arms. Contrarily, it was announced that Zapad-17 would test a mobilization (reserve) system, territorial defense ${ }^{183}$, effectiveness of civil defense and involvement of federal institutions ${ }^{184}$, but after the exercise there were not so many success stories regarding these trials.

It appears as if Russia undertakes strategic exercises not only as a tool to check plans and forces, but also as a strategic communication instrument that can have an impact on the existing security situation. Whether by accident or not, but the decision to emphasize one or another element during different official exercises was obvious. For example, Zapad-09 emphasized a tactical nuclear strike which could be taken as a strategic deception (deterrence) message; with the openness and transparency it exhibited in Zapad-17, showing its readiness for mass defense and the use of nuclear weapons, Russia sent a clear message not to push it "into a corner".

And to conclude, the change in the military and other areas from 1999 demonstrates that Russia is not only declaring that it is in a league of its own, but is also trying to back such declarations up with action. In the military sphere, Russia maintains and develops a different (compared to the West and

\footnotetext{
${ }^{183}$ Even though the commander of the $11^{\text {th }}$ Reserve Command Col. Jurij Shtondenko (Юрий Штонденко), was appointed, active participation of reservists in Zapad-17 exercises was hardly presented in open sources.

${ }^{184}$ Russian President Decree No. 345 from 29072017 authorizes the National Guard (Rusguar) to be involved actively in all military activities. Despite this, there are almost no messages in open sources about Rusguard participation in Zapad-17.
} 
NATO) understanding about the way to plan and run operations and activities. This understanding is based on the philosophy of the Prussian General Staff. Since WW II, the West (NATO) has rejected this philosophy and it has almost been forgotten. Russia, on the other hand, exploits this aspect, therefore quite often its behavior is misinterpreted in the West and prognoses based on Western forecasting principles fail.

Trakai, 3 November 2017 